\title{
Theoretical evaluation of bortezomib and other boron-containing compounds as inhibitors of SARS-CoV-2 main protease.
}

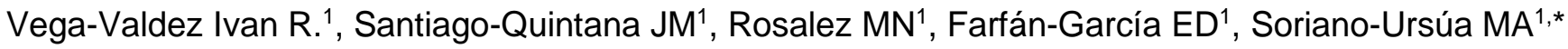 \\ 1 Sección de Estudios de Posgrado e Investigación, Escuela Superior de Medicina, Instituto Politécnico \\ Nacional, Plan de San Luis y Diaz Miron s/n, Mexico City, 11340, México.
}

\begin{abstract}
Background: Boronic acids are attractive chemical agents in drug design, some data confer them attractiveness for proteases inhibition. Objective: The aim of the present docking study was to explore the putative role of boronic moieties in molecules interacting on the binding site of the SARS-CoV-2 main protease. Method: The methodology was based on the conventional docking procedure by means of AutoDock software by assaying boron-free and boron-containing compounds on the recent reported crystal structure of SARS-CoV-2 main protease (PDB code: 6LU7). Results: The most of tested compounds share contact with key residues and poses on the cleavage pocket. Those compounds with a boron atom in its structure often were estimated with higher affinity than boron-free analogues. Conclusions: Interactions and affinity of boroncontaining peptidomimetics on the binding site let us to propose the potent inhibition of these compounds on targeted protease. These advances may be relevant for drug designing, but also to suggest the testing of available boron-containing drugs in patients with severe symptoms of COVID19 infection.
\end{abstract}

Keywords: Boron; boronic acids; oligopeptides; bortezomib; protease inhibitors, COVID19.

* Address correspondence to author at the Escuela Superior de Medicina, Instituto Politécnico Nacional, Mexico City, Mexico; Tel: +52-57296000-62747; E-mail: msoriano@ipn.mx 


\section{INTRODUCTION}

Inclusion of boron atom into chemical structures is attractive for drug design [1-3]. Diverse boronmoieties attached to organic compounds have resulted in the generation of compounds with potent biological activity $[4,5]$.

Among Boron-containing compounds (BCCs) there are those attractive for their ability to inhibit enzymes $[6,7]$. Some of them have been tested as proteases inhibitors, and some details about its interaction are known from 3D crystal structures [8-10].

COVID19, disease caused by SARS-CoV-2 infection is increasing, and currently is considered a pandemic event with high global burden. Several targets and strategies for limiting the progression and damage of this virus is being studied and used [11-13]. Among these are drug administration strategies to limit the infection and cell damaging induced by this virus. Some new and recently developed drugs are been suggested, but also some other in use in humans (with previous approbation by FDA and other regulator institutions) are being tested or repurposed as for potential use in this pandemic condition [14,15].

Among the main targets are, the spike protein related to the Angiotensin Converting Enzyme-2, the RNA-dependent RNA polymerase (RdRp), and proteases of SARS-CoV-2, such as the nonstructural protein 3CL-Pro [16,17]; actives on these targets are lopinavir, ritonavir and ribavirin [18]. But also, other drugs with unclear mechanism of action are being included in the set for treating COVID19 infection, such as chloroquine and arbidol [18]. Besides, some crystal structures of these and other SARS-CoV-2 proteins are solved and deposited in Protein Data Bank, while others are being reported as they are built by using diverse methods of molecular modeling [19]. These structures can be useful for increasing velocity to identify promising drugs.

In this sense, boronic acids and some oligopeptides with boron in its structure are actives on viral proteases [8-10]. The advances in this sense have drove to the evaluation of some of them in humans. Moreover, some of these are available for human administration, albeit if its probed action is on some types of neoplasia [20-22]. Its administration on humans with virus infection have yield attractive results; such as blocking of Severe fever with thrombocytopenia syndrome virus or inhibition of influenza virus growth [23,24]. Among them are the well-known proteasome inhibitors bortezomib, ixazomib and delanzomib. These compounds are interesting due to the ability to interact on these targets, but also due to the structural similarity to some drugs recently tested in the current COVID19 pandemic [18] or suggested as high affinity ligands on main targeted proteins or RNA-protein complexes $[9,25,26]$.

In the current contribution the interactions of BCCs on the SARS-CoV-2 main protease (COVID19-Mpro) are described. The analysis is centered in the role of boron atom in the included structures as well as the viability of such compounds to act as potential inhibitors of the enzyme, then, as potential drug to treat COVID19 infection. 


\section{METHODS}

\subsection{Selection and retrieval/building of tested structures.}

The structures of a group of 140 ligands were drawn using ChemBioDraw Ultra 12.0 (CambridgeSoft, Cambridge, MA 02140). This group included boronic acids (Suppl. Table 1), a set of boroxazolidones adducts of borinic acid and amino acids (Suppl. Table 2, as some of them were recently proposed as potent inhibitor of enzymes [27]), and a set of oligopeptides structurallyrelated to bortezomib (including its metabolites, Suppl. Table 3), those crystallyzed on viral proteases (Suppl. Table 4) and structurally related to a potent inhibitor of the target protein (Suppl. Table 5) [26], as well as the boron-free analogues. For those ligands not obtained from crystals, their geometry was pre-optimized by using Hyperchem (Version 6.0, Hypercube, USA) at the level of molecular mechanics (AM1 basis set). Therefore, the minimum energy structure for each ligand was fully optimized at the B3LYP/6-31G** level by using Gaussian 09 software.

The structure of COVID19-Mpro (PDB ID:6LU7) was selected due to their availability, the recentness of its releasing and due to the enclosure of one compound suggested as potent ligand (and some boron-containing analogues) from a previous analysis on it [26].

\subsection{Docking procedure}

The targeted protein was prepared by removing water molecules and other ligands. AutoDock Tools 1.5.6 was used to prepare docking studies. Firstly, a blind approach was employed to explore binding in the whole protein and thus identify or discard putative allosteric binding sites. Secondly, we used a pair of recent developed (Prank-Web and ArDock) servers to found additional protein surfaces to be considered as putative binding sites on the targeted protein $[28,29]$. As no other relevant sites were found (see results), a grid-box of $60 \times 60 \times 60 \AA$ was centered on the site where the compound $n-[(5$-methylisoxazol-3-yl) carbonyl] alanyl-I-valyl-n 1 $((1 r, 2 z)-4$-(benzyloxy)-4-oxo-1-\{[(3r)-2-oxopyrrolidin-3-yl] methyl\} but-2-enyl)---leucinamide was removed from the crystallized enzyme.

A Lamarckian genetic algorithm was used to perform the search with an initial population of 100 random individuals, and $1.0 \times 10^{7}$ iterations were run with the AutoDock 4.2 software [30]. The results were analyzed for affinity values estimation and interactions with AutoDockTools 1.5.6 [31] and Visual Molecular Dynamics 1.9.2 [32], and images were obtained by using VMD or Discovery Studio (BIOVIA, D. S. 2015, San Diego, Dassault Systemes, Release, 4). To validate the docking procedure, the re-docking of the removed ligand on the enzyme was performed and evaluated. 


\section{RESULTS AND DISCUSSION}

\subsection{Analysis of the targeted protein}

The COVID19-Mpro has a well identified binding site for known inhibitors as well as its topology has been well described [33-35]. Additional surfaces are suggested as binding areas (Fig. 1).

The current analysis is centered in the cleavage site since this is a well-known interior area related to the catalytic site and most of the compounds crystallized or docked on this protein fit into this site.

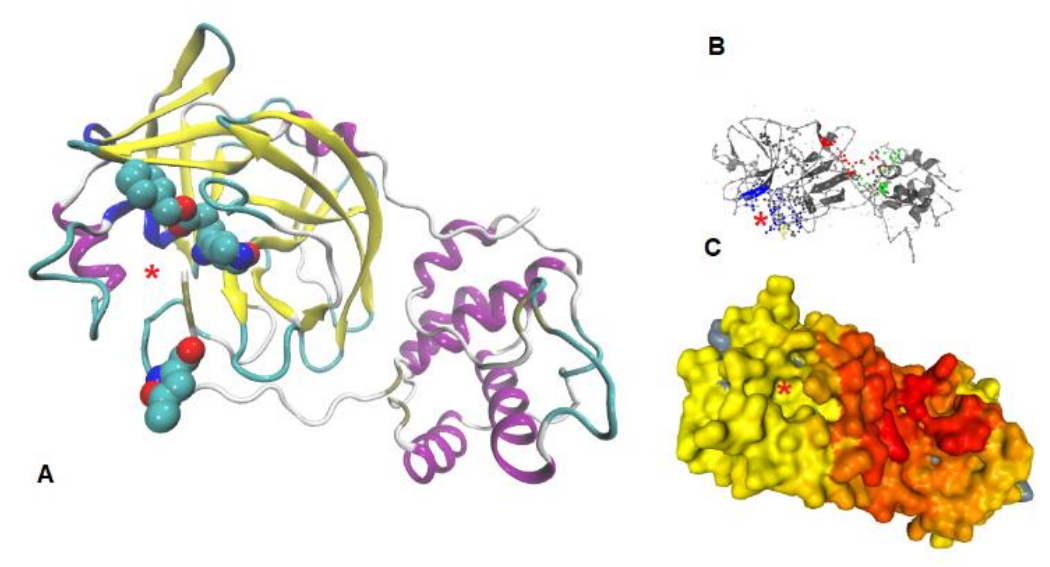

Fig. 1. The COVID19-Mpro with ligands on the crystalized structure (A, PDB ID:6LU7). Sites (B) and surfaces (C) identified as potential cleavage areas. Red asterisk marks the cleavage site explored and discussed in this manuscript.

In addition, the targeted site was identified as the most favorable site for binding from the used servers [28,29]. All subsites or clusters of residues were included as part of the same region for easy description [26]. Moreover, central discussion is in the ability of ligands to interact with the catalytic dyad and residues in the cluster of recognition.

\subsection{Analysis of docking modes and estimated energy and affinity.}

Docking procedure used in the current work let one to get the same pose of crystallized ligand on the target protein (Fig. 2). The RMSD between crystallized and redocked ligand N3 was $<1.0 \AA$. 


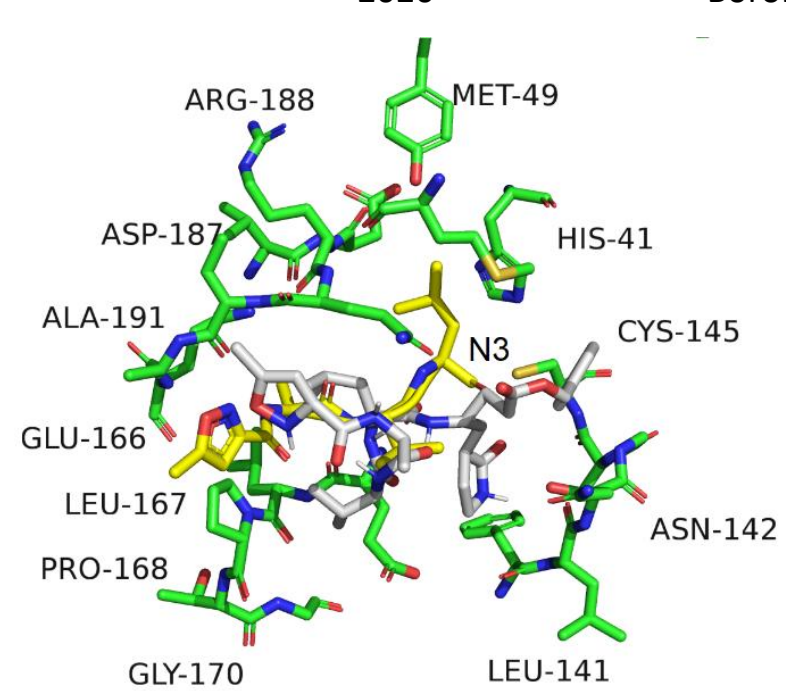

Fig. 2. The superimposition of the crystalized and docked ligand N3 on the MPro of COVID19 (PDB ID:6LU7).

About the site for the most of ligands, it should be noted that albeit a wide grid-box of $60 \times 60 \times 60 \AA$ was used on the targeted protein -letting access to a big surface for docking-, the highest affinity poses were often in the cleavage site where the ligand N3 is in the crystalized protein (Suppl Fig. 1). Furthermore, although some small molecules as boronic acids reach sites out of this site, and just three of the twenty boroxazolidones docked out of the binding site, this site was constant for all structures with at least two peptide or peptidomimetic residues.

Hence, the pose of the docked compounds seems to be adequate to disrupt the activity of the enzyme since is near of the Cys145-His164 catalytic dyad, in a cleft between Domains I and II [36] as often occurs in some related viral proteases [37]. COVID19-Mpro inhibition could clearly impact in the virus replication. If well other targets could explain the effects of these compounds in the SARS-CoV-2 infection processes as the probed feasibility of some BCCs to interact on other targets as the RdRp [38] or the modification of the cytokines and factors related with immune response to viral infection [38,39].

Regarding the affinity values, the lowest affinity was for some carbon-based molecules analogues to the boronic acids (the first twenty-one blank circles on the left in Fig. 3). Then, for the boronic acids (particularly for para and meta halogen-substituted phenylboronic acids). Following to them, for the carbon-based analogues to boroxazolidones; then, boroxazolidones. While the highest estimated values were for those oligopeptides or peptidomimetics -including bortezomib and its metabolites- particularly for those containing a boron atom in its structure (Fig. 3). In this sense, it was notable that estimated values are often lower for those carbon based (or boron-free compounds), albeit high similarity of compounds. This was more noticeable for the last set as boronic acids and its analogues had differences approximately of an order of magnitude (1 unit in the logarithmic scale), while the difference for boron-containing peptides and its analogues was higher (often between one and two orders of magnitude). 
In this sense, there are four examples: The boron-free bioisostere of bortezomib showed a lower affinity value than bortezomib, conferring to the latter a 5 -fold higher affinity (Suppl. Fig. 2). Also, this was for the molecule with the highest estimated affinity on the cleavage site of Mpro, a boroncontaining peptidomimetic molecule (Q1D) recently tested on the HIV-1 wild type protease [8]. In that case, boron moeity conferred a 4-fold higher affinity than that for boron-free analog (Suppl. Fig. 3). As a third example, is the difference between the compound suggested as the hit compound (ZINC000541677852) among 1.3 billion of compounds tested in a recent theoretical work [26]; in that case, the substitution of a carbon with three fluoride atoms by a boron atom with two hydroxyls confers also a 4-fold higher affinity (Suppl. Fig. 4). Finally, the greater difference between analogue-structures was for compound (BE8) tested as a potent inhibitor on the HCVNS3 protease [40], in these molecules the estimated affinity value suggests 100 -fold lower affinity for the boron-free analogue. In all these exampling cases the compounds reach the cleavage site, but in the latter, the boron-free compound is docked in the entrance of this site with no ability to reach the catalityc dyad (Suppl. Fig. 5).

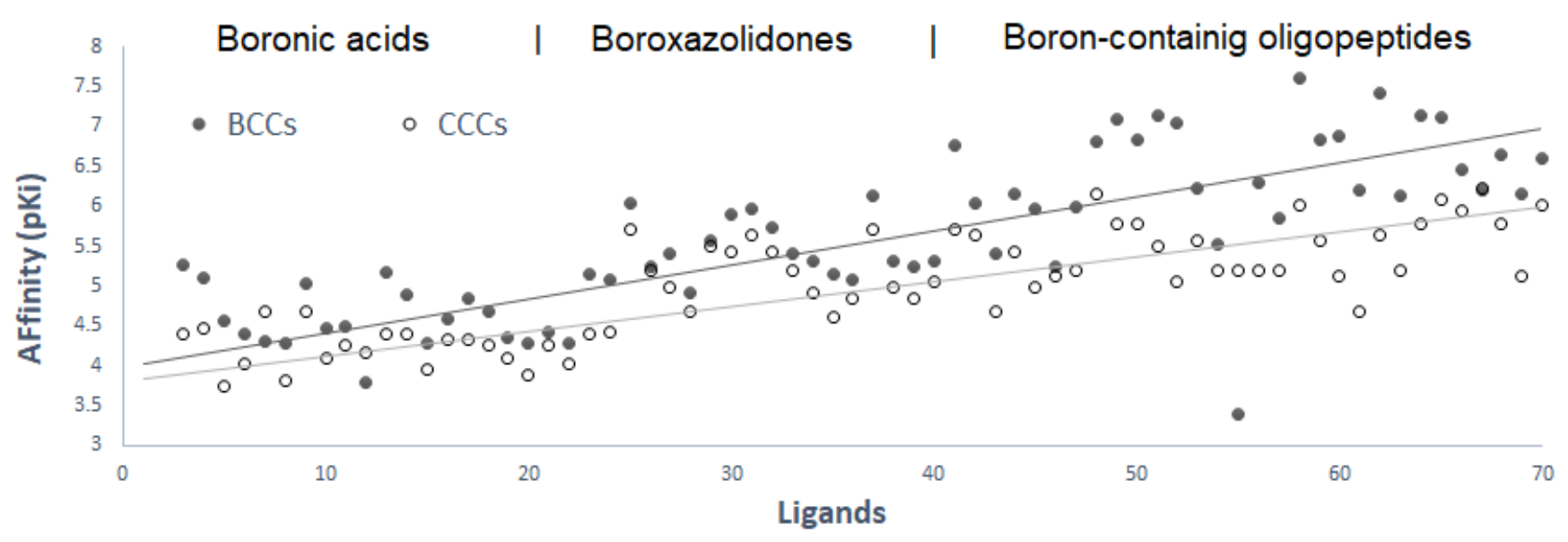

Fig. 3. Affinity values of tested ligands on COVID9-Mpro. The filled circles are for BCCs, while blank circles are for CCs. Each compound is in line with this analogue. The pki (-log ki) values are directly related to estimated affinity. The values are for boronic acids for the first 21 values on the left, then the 22 to 41 values are for amino acid boroxazolidones derivatives, and the last on the right are for boron-containing oligopeptides (including bortezomib, ixazomib, delanzomib and some metabolites of these compounds tested in humans). BCCs: Boron-containing compounds, CCCs: Carbon-containing analogues. 
The key interactions for the estimated affinity and potential inhibitory activity were difficult to identify due to most of tested ligands are docked in the cleavage site. But a key role is suggested for some hydrogen bonds, Van der Waals, hydrophobic and pi-pi interactions of tested compounds, as well as the ability of boron atom and the hydroxyls linked to this atom for interacting direct or nearby of the catalytic dyad.

Judged for the analysis of the compounds with highest affinity. Both, number of contacts with residues in the cleavage site and the boron atom presence seems to be relevant. As you can see for the hit compound (that with the highest estimated affinity in this work, reported previously as a Potent HIV-1 Protease Inhibitors Containing Carboxylic and Boronic Acid) in the Fig. 4, the most common interaction are by means of van der Waals forces with backbone and sidechains of residues in the crevice near of the catalytic site. But also, pi-pi shaped, amide-pi stacked and alkyl-pi interactions were common in the compounds with high affinity. The moieties with boron atom were often directed towards the dyad, or towards residues in the segment to 165 to 168 (Fig. 4 and Suppl. Fig. 6). Any case, is noticeable the feasibility of hydroxyl moieties linked to boron atom to form conventional hydrogen bonds with sidechains of near residues (as it has been found or suggested on other targets) [41,42], while this is not frequent in the analogue carbon-linked hydroxyl groups.

A

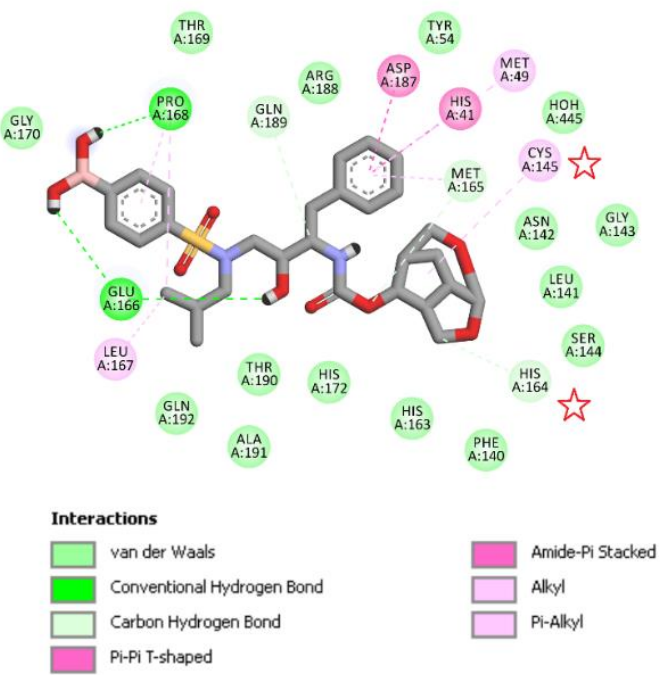

B

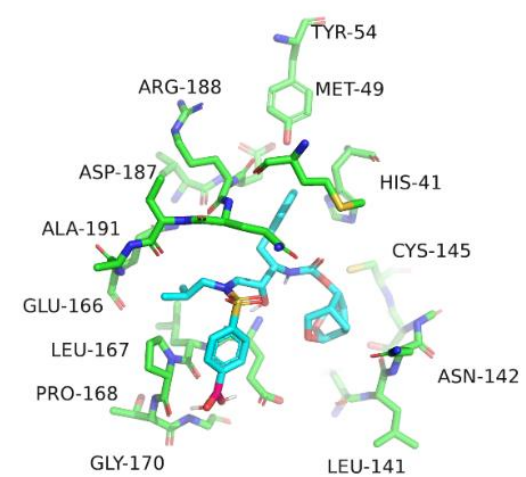

Fig. 4. The interactions of the hit-compound $\{4-[\{(2 \mathrm{R}, 3 \mathrm{~S})-3-[(\{[(3 \mathrm{~S}, 3 \mathrm{aR}, 5 \mathrm{R}, 7 \mathrm{aS}, 8 \mathrm{~S})-$ hexahydro- $4 \mathrm{H}-$ 3,5-methanofuro [2,3-b]pyran-8-yl]oxy\}carbonyl)amino]-2-hydroxy-4-phenylbutyl\}(2methylpropyl)sulfamoyl]phenyl\}boronic acid (PDB ligand code: Q1D) on the MPro of COVID19 (PDB ID:6LU7). A. 2D representation, red stars are in the residues of the catalytic dyad. B. 3D representation of docking into the cleavage site. 
On the other hand, albeit some effects on the immune system suggest the proteasome inhibitors can increase the susceptibility to viral infections $[43,44]$. Multiple reports have sentenced that these drugs could be option to treat established infections.

In this sense, the peptidomimetic bortezomib was approved for human use since 2003. This drug has been tested in several viral infections, the attractive data from these applications include blocking of severe fever with thrombocytopenia syndrome virus or inhibition of influenza virus growth, $[23,24]$ the blockage of early infection by herpes simplex virus [45], is suggested as repurposed drug to treat the zoonotic disease Japanese encephalitis [46] or the zika virus infection [47]. Moreover, this drug has been tested in cells and mice infected with coronavirus, observing controversial results $[39,48-50]$. Ixazomib was approved for treating multiple myeloma in 2015; just a few data are regarding viral infections for this compound, some suggesting it increases death for cells infected with Human immunodeficiency virus[51] and other suggesting growth-inhibitory effects on cells infected by EpsteinBarr virus [52]. Awhile, the development of delanzomib for myeloma was discontinued due to high incidence of adverse effects in humans [53]. Among these BCCs tested in humans, our results suggest bortezomib as the most potent compound against the COVID19-Mpro, but the affinity for the other two compounds are similar to that for bortezomib, while all three docked in the same site with similar mode (Fig. 5). This suggestion should be considered for being applied in near future in in vitro assays or maybe in severe cases of infection by SARS-CoV-2 due to the high burden of this pandemic. Even if also the high-cost of these drugs as well as those related to the monitoring of their side-effects should be taken into account.

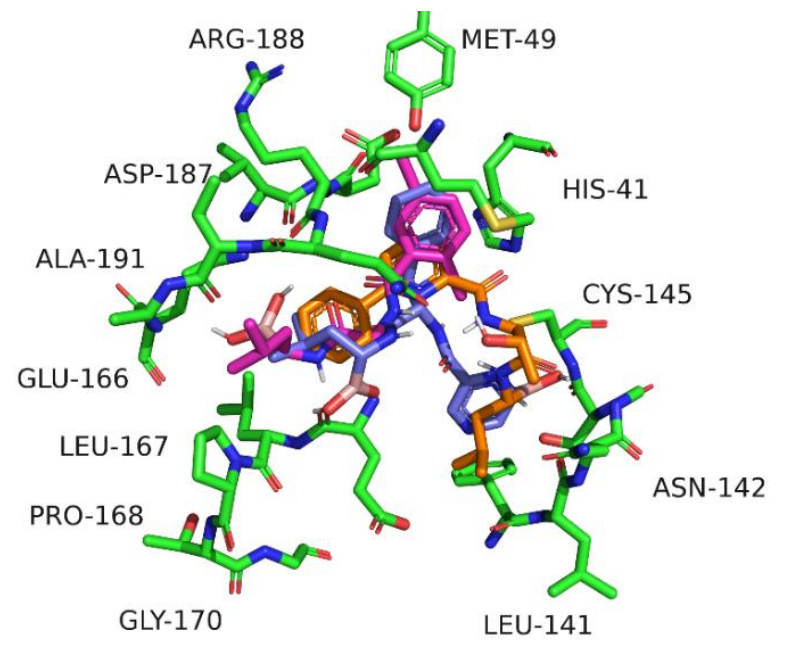

Fig. 5. The boron-containing peptidomimetics used in humans (Bortezomib, ixazomib and delanzomib) on the cleavage site of COVID19-MPro. 
Taken all above mentioned into account, our theoretical results strongly suggest peptidomimetics are candidates to develop and design new drugs for SARS-CoV-2 infections. Additional in vitro studies are desirable and required to evaluate coherence of the data observed in these theoretical assays; as well as to investigate the role of boron atom in the increased affinity values yielded from current docking procedures.

\section{CONCLUSIONS}

With the application of conventional docking procedure, it was possible to evaluate the feasibility of BCCs to reach the main targeted site for drug designing on the COVID19-Mpro. That ability was advantageous for those boron-containig peptidomimetics, since simple boronic acids showed several binding sites, including some out of the well-known cleavage site, and alpha amino acid boroxazolidones have contact on just a part of the cleavage site suggested as key for inhibition.

The results are in line with experimental observations suggesting higher affinity of BCCs than that observed for boron-free compounds. But also, they support the intention for designing boron-containing peptidomimetics as potential drugs for viral infections.

Interactions of boron atom seem to be relevant for the predicted higher affinity of those compounds containing it. However, different types of interactions for boron atom or the linked hydroxyl groups were found. Being the most common on the residues in the catalytic dyad, but also with the residues Glu166 or Leu167 by means of hydrogen bonds or by electrostatic forces.

Additionally to the idea of boron-containing peptidomimetics are attractive for drug design against SARS-CoV-2 infection; the results in this manuscript suggest potential to some BCCs approved for human use (bortezomib, ixazomib and delanzomib) for being tested as potential repurposed drugs for viral infections, such as the current COVID19 pandemic.

Some of the resulting data correspond with previous finding. Further research is necessary to establish a carefully quantitative structure-activity relationship of boroncontaining oligopeptides for increasing the possibility to get selective, potent and efficient inhibitors of COVID19-Mpro. 


\section{CONFLICT OF INTEREST}

The authors declare they have no conflict of interest about the content of this work.

\section{ACKNOWLEDGEMENTS}

The authors gratefully acknowledge the support provided by the Secretaría de Investigación y Posgrado of the IPN (SIP-M1930), and the Consejo Nacional de Ciencia y Tecnología.

\section{SUPPLEMENTARY MATERIAL}

Supplementary material includes five tables with the structure of the tested ligands and 1 with the affinity values. But also, six figures about the binding sites observed in docking assays (Fig. S1); comparative docking of boron/carbon-based compounds (Fig. S2-S5) and interactions map for the three BCCs used in humans (Fig. S6).

\section{REFERENCES}

[1] Soriano-Ursúa, M.A.; Das, B.C.; Trujillo-Ferrara, J.G. Boron-Containing Compounds: Chemico-Biological Properties and Expanding Medicinal Potential in Prevention, Diagnosis and Therapy. Expert Opinion on Therapeutic Patents, 2014, 24, 485500

[2] Ban, H.S.; Nakamura, H. Boron-Based Drug Design. Chem. Rec., 2015, 15, 616-35.

[3] Fernandes, G.F.S.; Denny, W.A.; Dos Santos, J.L. Boron in Drug Design: Recent Advances in the Development of New Therapeutic Agents. Eur. J. Med. Chem., 2019, 179, 791-804.

[4] Farfán-García, E.D.; Castillo-Mendieta, N.T.; Ciprés-Flores, F.J.; Padilla-Martínez, I.I.; Trujillo-Ferrara, J.G.; Soriano-Ursúa, M.A. Current Data Regarding the Structure-Toxicity Relationship of Boron-Containing Compounds. Toxicology Letters, 2016, $258,115-125$.

[5] Soriano-Ursúa, M.A.; Farfán-García, E.D.; Geninatti-Crich, S. Turning Fear of Boron Toxicity into Boron-Containing Drug Design. Curr. Med. Chem., 2019, 26, 5005-5018.

[6] Nocentini, A.; Supuran, C.T.; Winum, J.-Y. Expert Opinion on Therapeutic Patents Benzoxaborole Compounds for Therapeutic Uses: A Patent Review (2010-2018). Benzoxaborole Compounds for Therapeutic Uses: A Patent Review (2010-2018). Expert Opin. Ther. Pat., 2018, 28, 493-504.

[7] Krajnc, A.; Lang, P.A.; Panduwawala, T.D.; Brem, J.; Schofield, C.J. Will Morphing Boron-Based Inhibitors Beat the $\beta$ Lactamases? Current Opinion in Chemical Biology, 2019, 50, 101-110.

[8] Ghosh, A.K.; Xia, Z.; Kovela, S.; Robinson, W.L.; Johnson, M.E.; Kneller, D.W.; Wang, Y.F.; Aoki, M.; Takamatsu, Y.; Weber, I.T.; Mitsuya, H. Potent HIV-1 Protease Inhibitors Containing Carboxylic and Boronic Acids: Effect on Enzyme Inhibition and Antiviral Activity and Protein-Ligand X-Ray Structural Studies. ChemMedChem, 2019, 14, 1863-1872.

[9] Windsor, I.W.; Palte, M.J.; Lukesh, J.C.; Gold, B.; Forest, K.T.; Raines, R.T. Sub-Picomolar Inhibition of HIV-1 Protease with a Boronic Acid. J. Am. Chem. Soc., 2018, 140, 14015-14018.

[10] Nitsche, C.; Zhang, L.; Weigel, L.F.; Schilz, J.; Graf, D.; Bartenschlager, R.; Hilgenfeld, R.; Klein, C.D. Peptide-Boronic Acid Inhibitors of Flaviviral Proteases: Medicinal Chemistry and Structural Biology. J. Med. Chem., 2017, 60, 511-516.

[11] Meo, S.A.; Alhowikan, A.M.; Al-Khlaiwi, T.; Meo, I.M.; Halepoto, D.M.; Iqbal, M.; Usmani, A.M.; Hajjar, W.; Ahmed, N. Novel Coronavirus 2019-NCoV: Prevalence, Biological and Clinical Characteristics Comparison with SARS-CoV and MERSCoV. Eur. Rev. Med. Pharmacol. Sci., 2020, 24, 2012-2019.

[12] Tuite, A.R.; Bogoch, I.; Sherbo, R.; Watts, A.; Fisman, D.N.; Khan, K. Estimation of COVID-2019 Burden and Potential for International Dissemination of Infection from Iran. Ann Int Med, 2020, DOI: 10.7326/M20-0696.

[13] Zhou, F.; Yu, T.; Du, R.; Fan, G.; Liu, Y.; Liu, Z.; Xiang, J.; Wang, Y.; Song, B.; Gu, X.; Guan, L.; Wei, Y. Articles Clinical Course and Risk Factors for Mortality of Adult Inpatients with COVID-19 in Wuhan, China : A Retrospective Cohort Study. Lancet, 2020, DOI:10.1016/S0140-6736(20)30566-3.

[14] Li, H.; Wang, Y.M.; Xu, J.Y.; Cao, B. Potential Antiviral Therapeutics for 2019 Novel Coronavirus. Zhonghua Jie He He Hu Xi Za Zhi, 2020, 43 (3), 170-172.

[15] Fan, H.-H.; Wang, L.-Q.; Liu, W.-L.; An, X.-P.; Liu, Z.-D.; He, X.-Q.; Song, L.-H.; Tong, Y.-G. Repurposing of Clinically Approved Drugs for Treatment of Coronavirus Disease 2019 in a 2019-Novel Coronavirus (2019-NCoV) Related Coronavirus Model. Chin. Med. J. (Engl)., 2020, DOI:10.1097/CM9.0000000000000797.

[16] Liu, W.; Morse, J.S.; Lalonde, T.; Xu, S. Learning from the Past: Possible Urgent Prevention and Treatment Options for Severe Acute Respiratory Infections Caused by 2019-nCoV. ChemBioChem, 2020, 21 (5), 730-738.

[17] Wrapp, D.; Wang, N.; Corbett, K.S.; Goldsmith, J.A.; Hsieh, C.-L.; Abiona, O.; Graham, B.S.; McLellan, J.S. Cryo-EM 
Structure of the 2019-NCoV Spike in the Prefusion Conformation. Science, 2020, 367 (6483), 1260-1263.

[18] Liu, W.; Zhu, H.-L.; Duan, Y. Effective Chemicals against Novel Coronavirus (COVID-19) in China. Curr. Top. Med. Chem., 2020, DOI:10.2174/1568026620999200305145032.

[19] Dong, S.; Sun, J.; Mao, Z.; Wang, L.; Lu, Y.-L.; Li, J. A Guideline for Homology Modeling of the Proteins from Newly Discovered Betacoronavirus, 2019 Novel Coronavirus (2019-NCoV). J. Med. Virol., DOI: 10.1002/jmv.25768.

[20] Schrader, J.; Henneberg, F.; Mata, R.A.; Tittmann, K.; Schneider, T.R.; Stark, H.; Bourenkov, G.; Chari, A. The Inhibition Mechanism of Human 20S Proteasomes Enables Next-Generation Inhibitor Design. Science, 2016, 353 (6299), 594-598.

[21] Xi, J.; Zhuang, R.; Kong, L.; He, R.; Zhu, H.; Zhang, J. Immunoproteasome-Selective Inhibitors: An Overview of Recent Developments as Potential Drugs for Hematologic Malignancies and Autoimmune Diseases. European Journal of Medicinal Chemistry, 2019, 182, 111646.

[22] Colland, F. The Therapeutic Potential of Deubiquitinating Enzyme Inhibitors. Biochemical Society Transactions, 2010, 38,13743 .

[23] Liu, S.; Liu, H.; Zhang, K.; Li, X.; Duan, Y.; Wang, Z.; Wang, T. Proteasome Inhibitor PS-341 Effectively Blocks Infection by the Severe Fever with Thrombocytopenia Syndrome Virus. Virol. Sin., 2019, 34 (5), 572-582.

[24] Shahiduzzaman, M.; Ezatti, P.; Xin, G.; Coombs, K.M. Proteasomal Serine Hydrolases Are Up-Regulated by and Required for Influenza Virus Infection. J. Proteome Res., 2014, 13 (5), 2223-2238.

[25] Dai, Y.; Peralta, A.N.; Wynn, J.E.; Sherpa, C.; Li, H.; Verma, A.; Le Grice, S.F.J.; Santos, W.L. Molecular Recognition of a Branched Peptide with HIV-1 Rev Response Element (RRE) RNA. Bioorganic Med. Chem., 2019, 27 (8), 1759-1765.

[26] Ton, A.-T.; Gentile, F.; Hsing, M.; Ban, F.; Cherkasov, A. Rapid Identification of Potential Inhibitors of SARS- CoV-2 Main Protease by Deep Docking of 1.3 Billion Compounds. Mol. Inform., 2020, DOI:10.1002/minf.202000028.

[27] García, A.A.; Rayevsky, A.; Andrade-Jorge, E.; Trujillo-Ferrara, J.G. Structural and Biological Overview of Boron-Containing Amino Acids in the Medicinal Chemistry Field. Curr. Med. Chem., 2018, 26, 5077-5089.

[28] Reille, S.; Garnier, M.; Robert, X.; Gouet, P.; Martin, J.; Launay, G. Identification and Visualization of Protein Binding Regions with the ArDock Server. Nucleic Acids Res., 2018, 46, W417-W422.

[29] Jendele, L.; Krivak, R.; Skoda, P.; Novotny, M.; Hoksza, D. PrankWeb: A Web Server for Ligand Binding Site Prediction and Visualization. Nucleic Acids Res., 2019, 47, W345-W349.

[30] Morris, G.; Huey, R.; Linkstrom, W.; Sanner, M.; Belew, R.; Goodsell, D.; Olson. AutoDock4 and AutoDockTools4: Automated Docking with Selective Receptor Flexibility. J. Comput. Chem., 2010, 30, 2785-2791.

[31] Huey, R.; M. Morris, G.; Olson, A.J.; Goodsell, D.S. A Semiempirical Free Energy Force Field with Charge-Based Desolvation. J. Comput. Chem., 2007, 28, 1145-1152.

[32] Humphrey, W.; Dalke, A.; Schulten, K. VMD: Visual Molecular Dynamics. J. Mol. Graph., 1996, 14, 33-38.

[33] Pillaiyar, T.; Manickam, M.; Namasivayam, V.; Hayashi, Y.; Jung, S.H. An Overview of Severe Acute Respiratory SyndromeCoronavirus (SARS-CoV) 3CL Protease Inhibitors: Peptidomimetics and Small Molecule Chemotherapy. Journal of Medicinal Chemistry, 2016, 59 (14), 6595-628.

[34] Anand, K.; Ziebuhr, J.; Wadhwani, P.; Mesters, J.R.; Hilgenfeld, R. Coronavirus Main Proteinase (3CLpro) Structure: Basis for Design of Anti-SARS Drugs. Science, 2003, 300 (5626), 1763-1767.

[35] Kiemer, L.; Lund, O.; Brunak, S.; Blom, N. Coronavirus 3CLpro Proteinase Cleavage Sites: Possible Relevance to SARS Virus Pathology. BMC Bioinformatics, 2004, 5,72.

[36] Jin, Z.; Du, X.; Xu, Y.; Deng, Y.; Liu, M.; Zhao, Y.; Zhang, B.; Li, X.; Zhang, L.; Peng, C.; Duan, Y.; Yu, J.; Wang, L.; Yang, K.; Liu, F.; Jiang, R.; Yang, X.; You, T.; Liu, X.; Yang, X.; Bai, F.; Liu, H.; Liu, X.; Guddat, L.W.; Xu, W.; Xiao, G.; Qin, C.; Shi, Z.; Jiang, H.; Rao, Z.; Yang, H. Structure of Mpro from COVID-19 Virus and Discovery of Its Inhibitors. bioRxiv, 2020, DOI: $10.1101 / 2020.02 .26 .964882$.

[37] Zhou, J.; Fang, L.; Yang, Z.; Xu, S.; Lv, M.; Sun, Z.; Chen, J.; Wang, D.; Gao, J.; Xiao, S. Identification of Novel Proteolytically Inactive Mutations in Coronavirus 3C-like Protease Using a Combined Approach. FASEB J., 2019, 33 (12), 14575-14587.

[38] Bandi, P.; Garcia, M.L.; Booth, C.J.; Chisari, F. V.; Robek, M.D. Bortezomib Inhibits Hepatitis B Virus Replication in Transgenic Mice. Antimicrob. Agents Chemother., 2010, 54, 749-756.

[39] Ma, X.-Z.; Bartczak, A.; Zhang, J.; Khattar, R.; Chen, L.; Liu, M.F.; Edwards, A.; Levy, G.; McGilvray, I.D. Proteasome Inhibition In Vivo Promotes Survival in a Lethal Murine Model of Severe Acute Respiratory Syndrome. J. Virol., 2010, 84, $12419-12428$.

[40] Venkatraman, S.; Wu, W.; Prongay, A.; Girijavallabhan, V.; George Njoroge, F. Potent Inhibitors of HCV-NS3 Protease Derived from Boronic Acids. Bioorganic Med. Chem. Lett., 2009, 19, 180-183.

[41] Soriano-Ursúa, M.A.; Arias-Montaño, J.A.; Correa-Basurto, J.; Hernández-Martínez, C.F.; López-Cabrera, Y.; CastilloHernández, M.C.; Padilla-Martínez, I.I.; Trujillo-Ferrara, J.G. Insights on the Role of Boron Containing Moieties in the Design of New Potent and Efficient Agonists Targeting the B2 Adrenoceptor. Bioorganic Med. Chem. Lett., 2015, 25, 820-825.

[42] Soriano-Ursúa, M.A.; Bello, M.; Hernández-Martínez, C.F.; Santillán-Torres, I.; Guerrero-Ramírez, R.; Correa-Basurto, J.; Arias-Montaño, J.A.; Trujillo-Ferrara, J.G. Cell-Based Assays and Molecular Dynamics Analysis of a Boron-Containing Agonist with Different Profiles of Binding to Human and Guinea Pig Beta2 Adrenoceptors. Eur. Biophys. J., 2019, 48, 83-97.

[43] Basler, M.; Lauer, C.; Beck, U.; Groettrup, M. The Proteasome Inhibitor Bortezomib Enhances the Susceptibility to Viral Infection. J. Immunol., 2009, 183, 6145-6150.

[44] Yanaba, K.; Yoshizaki, A.; Muroi, E.; Hara, T.; Ogawa, F.; Shimizu, K.; Sato, S. The Proteasome Inhibitor Bortezomib Inhibits T Cell-Dependent Inflammatory Responses. J. Leukoc. Biol., 2010, 88, 117-122.

[45] Schneider, S.M.; Pritchard, S.M.; Wudiri, G.A.; Trammell, C.E.; Nicola, A. V. Early Steps in Herpes Simplex Virus Infection Blocked by a Proteasome Inhibitor. MBio, 2019, 10, e00732-19.

[46] Lv, B.M.; Tong, X.Y.; Quan, Y.; Liu, M.Y.; Zhang, Q.Y.; Song, Y.F.; Zhang, H.Y. Drug Repurposing for Japanese Encephalitis Virus Infection by Systems Biology Methods. Molecules, 2018, 23, 3346.

[47] Barrows, N.J.; Campos, R.K.; Powell, S.T.; Prasanth, K.R.; Schott-Lerner, G.; Soto-Acosta, R.; Galarza-Muñoz, G.; McGrath, E.L.; Urrabaz-Garza, R.; Gao, J.; Wu, P.; Menon, R.; Saade, G.; Fernandez-Salas, I.; Rossi, S.L.; Vasilakis, N.; Routh, A.; 
Bradrick, S.S.; Garcia-Blanco, M.A. A Screen of FDA-Approved Drugs for Inhibitors of Zika Virus Infection. Cell Host Microbe, 2016, 20,259-270.

[48] Raaben, M.; Grinwis, G.C.M.; Rottier, P.J.M.; de Haan, C.A.M. The Proteasome Inhibitor Velcade Enhances Rather than Reduces Disease in Mouse Hepatitis Coronavirus-Infected Mice. J. Virol., 2010, 84, 7880-7885.

[49] Schneider, M.; Ackermann, K.; Stuart, M.; Wex, C.; Protzer, U.; Schätzl, H.M.; Gilch, S. Severe Acute Respiratory Syndrome Coronavirus Replication Is Severely Impaired by MG132 Due to Proteasome-Independent Inhibition of M-Calpain. J. Virol., 2012, 86, 10112-10122.

[50] Raaben, M.; Posthuma, C.C.; Verheije, M.H.; te Lintelo, E.G.; Kikkert, M.; Drijfhout, J.W.; Snijder, E.J.; Rottier, P.J.M.; de Haan, C.A.M. The Ubiquitin-Proteasome System Plays an Important Role during Various Stages of the Coronavirus Infection Cycle. J. Virol., 2010, 84, 7869-79.

[51] Natesampillai, S.; Cummins, N.W.; Nie, Z.; Sampath, R.; Baker, J. V.; Henry, K.; Pinzone, M.; O’Doherty, U.; Polley, E.C.; Bren, G.D.; Katzmann, D.J.; Badley, A.D. HIV Protease-Generated Casp8p41, When Bound and Inactivated by Bcl2, Is Degraded by the Proteasome. J. Virol., 2018, 92, e00037-18.

[52] Ganguly, S.; Kuravi, S.; Alleboina, S.; Mudduluru, G.; Jensen, R.A.; McGuirk, J.P.; Balusu, R. Targeted Therapy for EBVAssociated B-Cell Neoplasms. Mol. Cancer Res., 2019, 17, 839-844.

[53] Vogl, D.T.; Martin, T.G.; Vij, R.; Hari, P.; Mikhael, J.R.; Siegel, D.; Wu, K.L.; Delforge, M.; Gasparetto, C. Phase I/II Studyof the Novel Proteasome Inhibitor Delanzomib (CEP-18770) for Relapsed and Refractory Multiple Myeloma. Leuk. Lymphoma, 2017, 58, 1872-1879. 


\section{Supplementary material}

\section{Theoretical evaluation of bortezomib and other boron-containing compounds as inhibitors of SARS-CoV-2 main protease.}

Vega-Valdéz Iván R., Santiago-Quintana JM, Rosalez MN, Farfán-García ED, Soriano-Ursúa MA*

Sección de Estudios de Posgrado e Investigación, Escuela Superior de Medicina, Instituto Politécnico Nacional, Plan de San Luis y Diaz Miron s/n, Mexico City, 11340, Mexico.

*Address correspondence to author at the Escuela Superior de Medicina, Instituto Politécnico Nacional, Mexico City, Mexico; Tel: +52 57296000-62747; E-mail: msoriano@ipn.mx

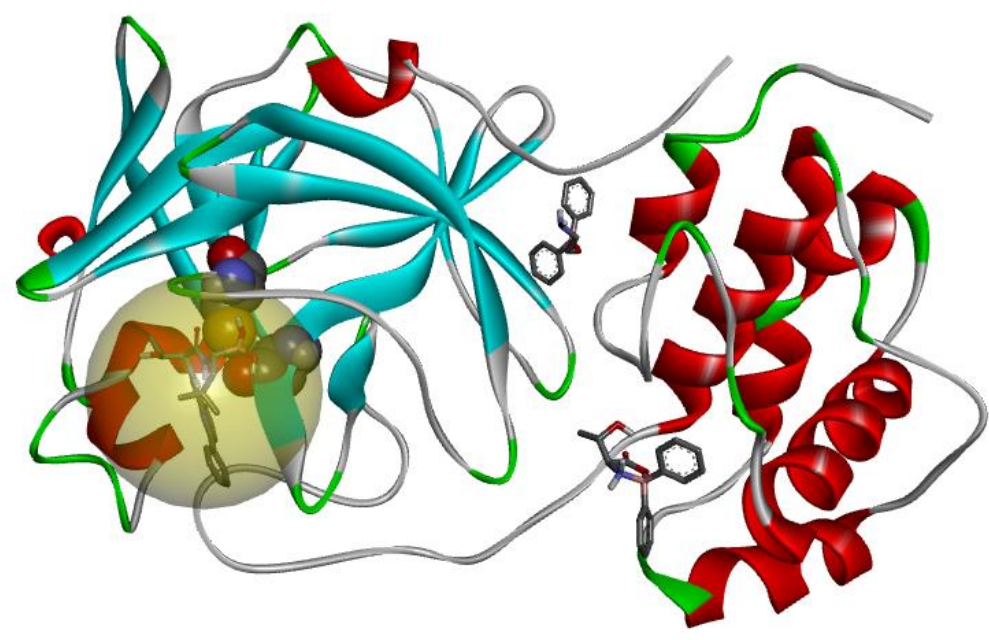

Fig. S1. Available docking sites on the COVID19-Mpro. The main cleavage site is as a transparent sphere and the residues of dyad (Cys145 and His164) are in bubble representation. Two alternative sites are marked with a docked BCC (as each is in the highest affinity pose). 


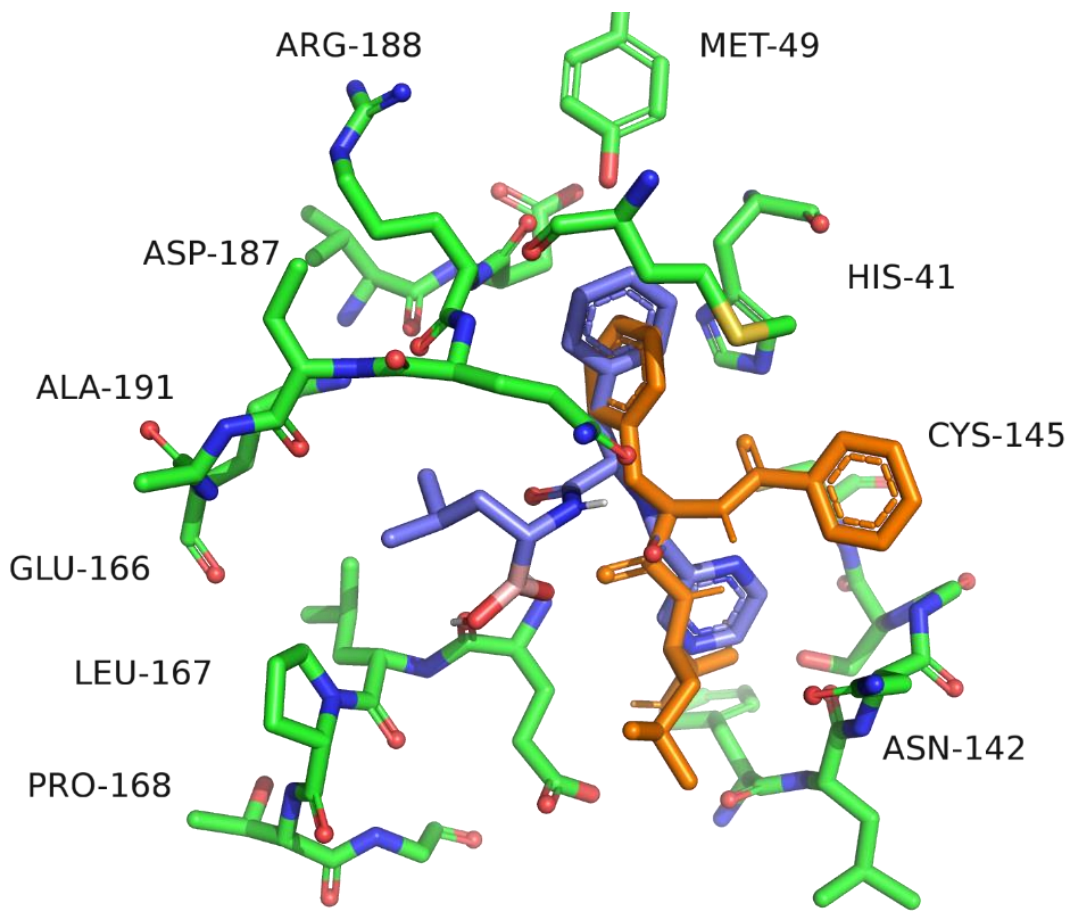

Fig. S2. Bortezomib (purple) and its boron-free analogue (orange). Both are in the cleavage site and in the highest affinity pose. The nearby of dyad is clear as Cys145 residue is visible in this representation. 


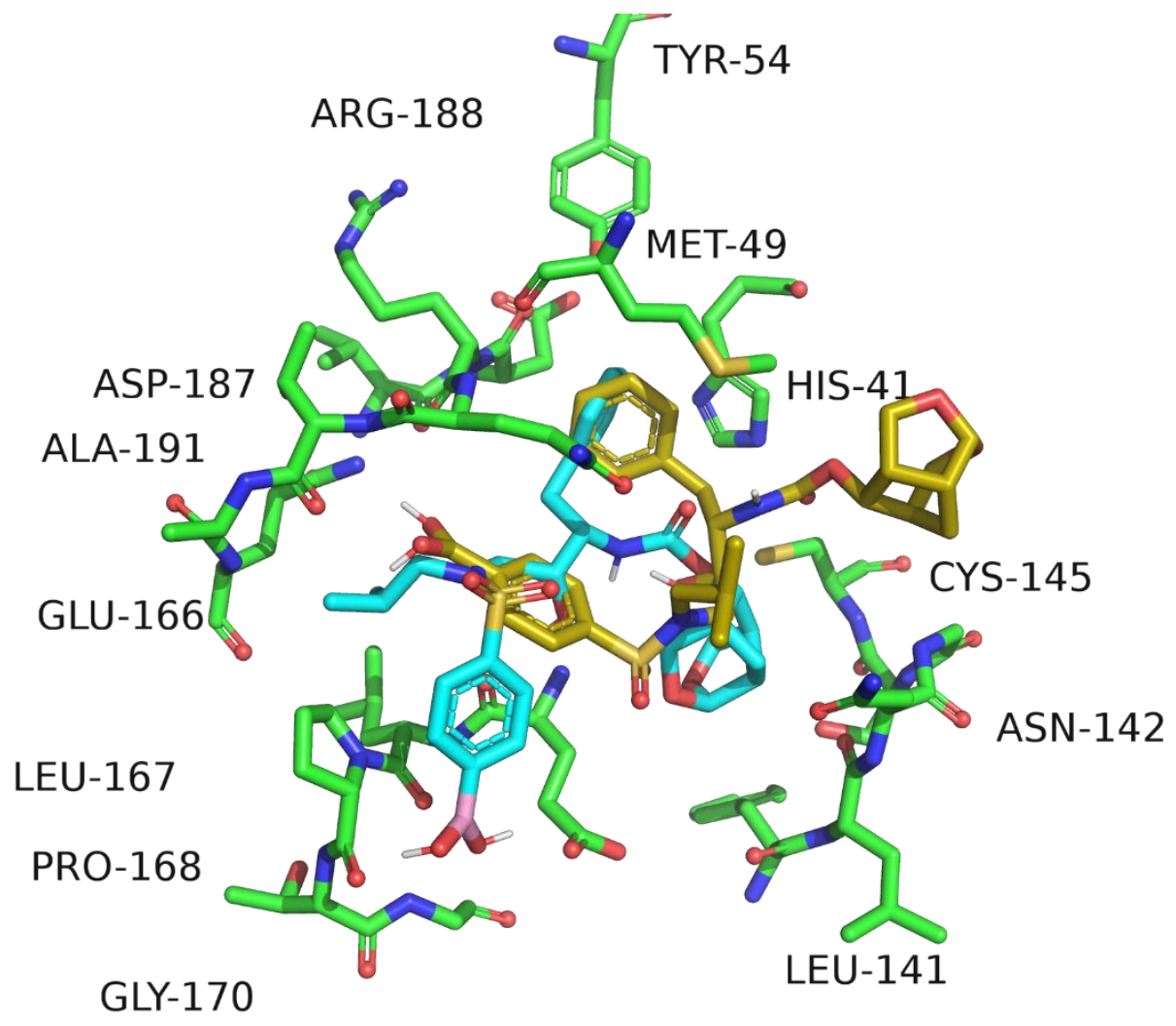

Fig. S3. The compound with Protein Data Base Code Q1D (cyan backbone) and its boron-free analogue (yellow backbone). Both are in the cleavage site and in the highest affinity pose. The nearby of dyad is clear as Cys145 residue is visible in this representation. 


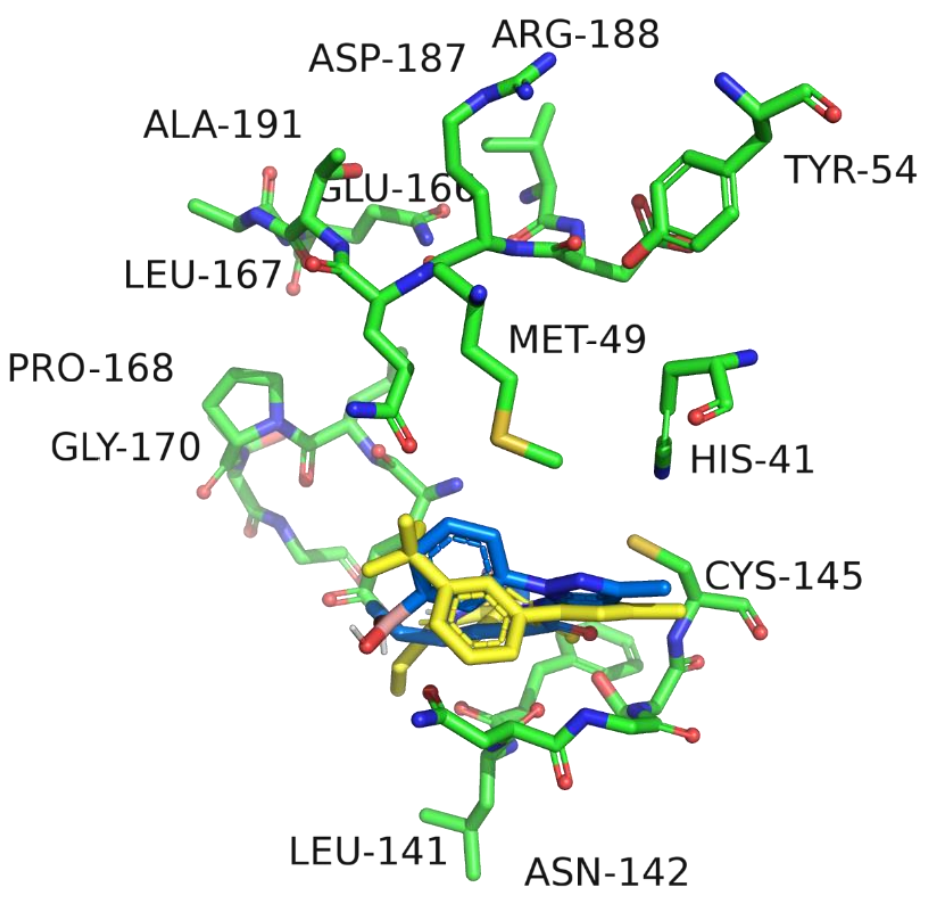

Fig. S4. The compound ZINC000541677852 (yellow) and its boron-containing analogue (blue backbone). Both are in the cleavage site and in the highest affinity pose. The nearby of dyad is clear as Cys145 residue is visible in this representation. ZINC000541677852 was considered a hit compound on a theoretical assay considering 1.3 billion of ligand as potential inhibitors of MproCOVID19 [1]. 


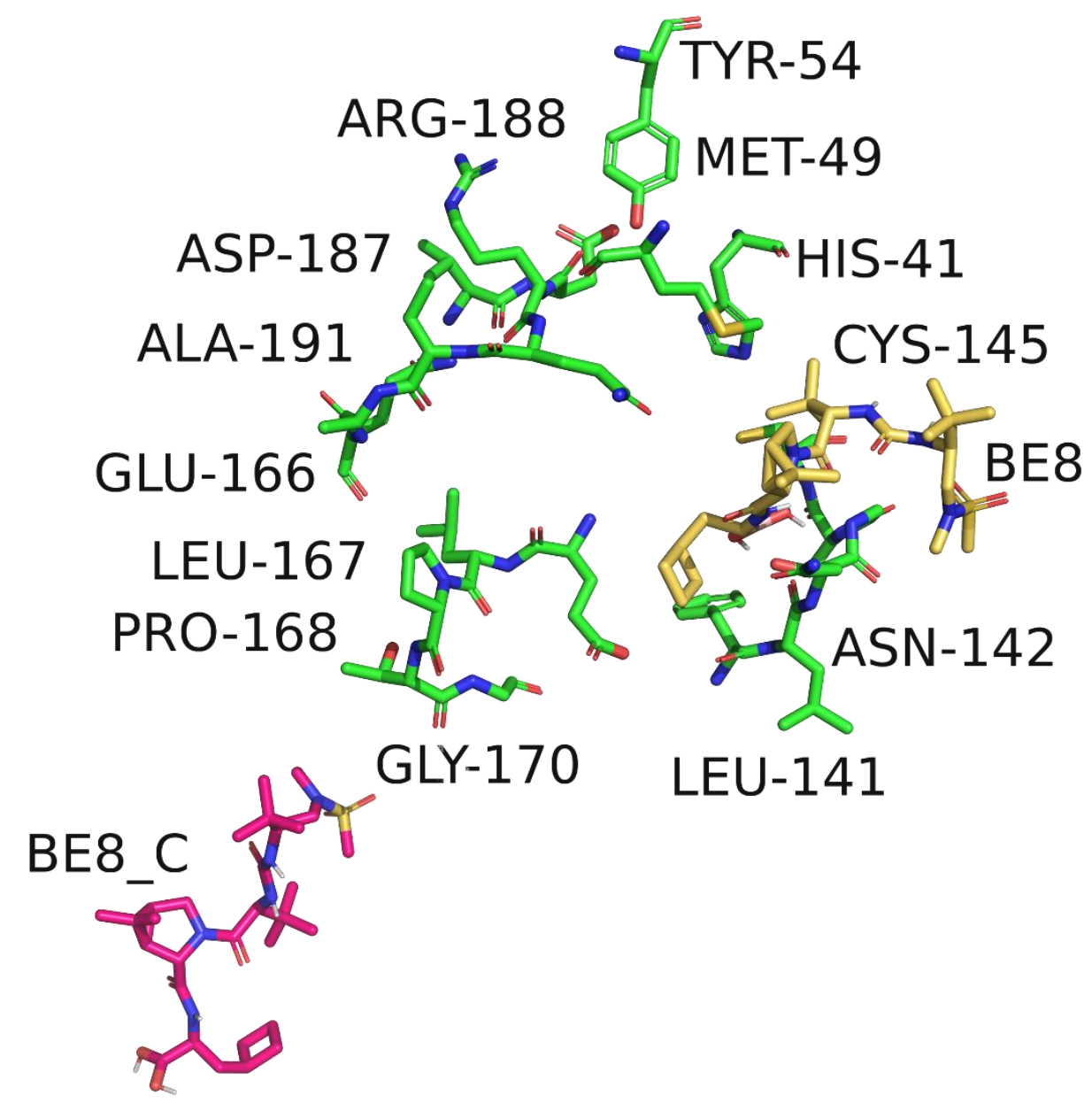

Fig. S5. The compound BE8 (a BCC, yellow backbone) and its boron-free analogue (BE8_C, pink backbone). It should be noted that BE8 is in the cleavage site, while BE8_C it is not in this site, both are in the highest affinity pose. The nearby of dyad is clear as Cys145 residue is visible in this representation. BE8 was previously tested as a potent inhibitor on the HCV-NS3 protease [2]. 

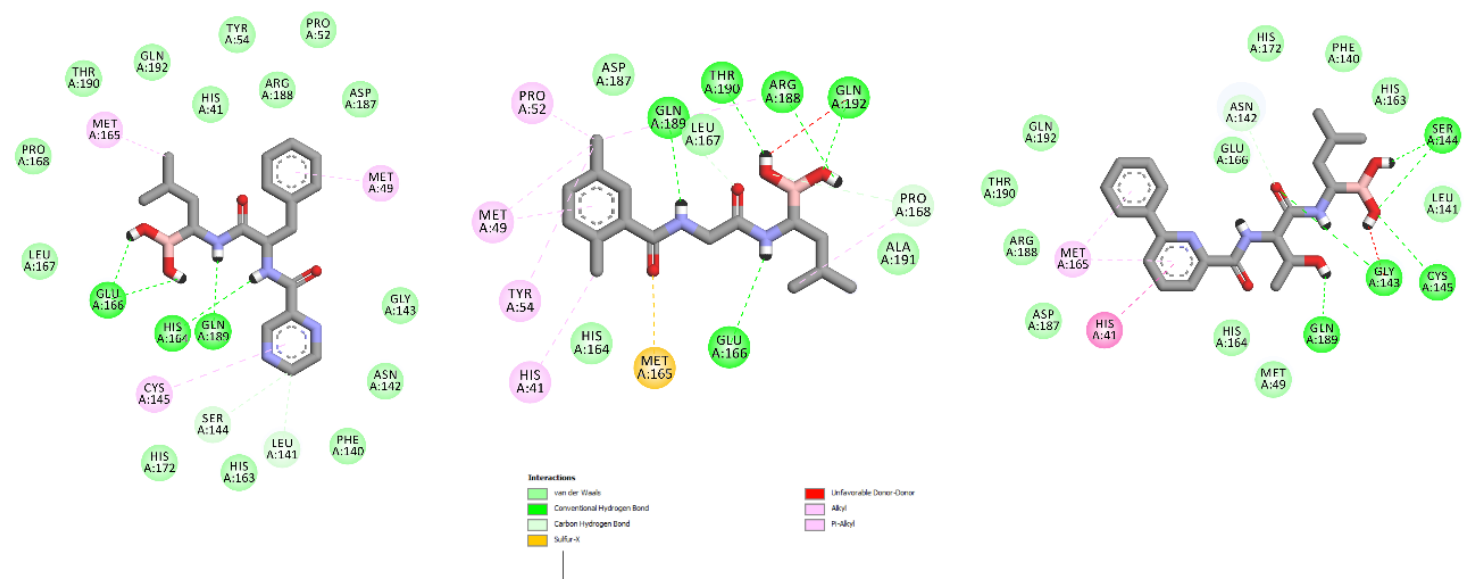

Fig. S6. Interaction-maps for bortezomib, ixazomib and delanzomib (from left to right) on MProCOVID19. Boron atom is in pink color 
Table 1. Boronic acids included in this study. Code was assigned and it corresponds to that in the table for affinity values.

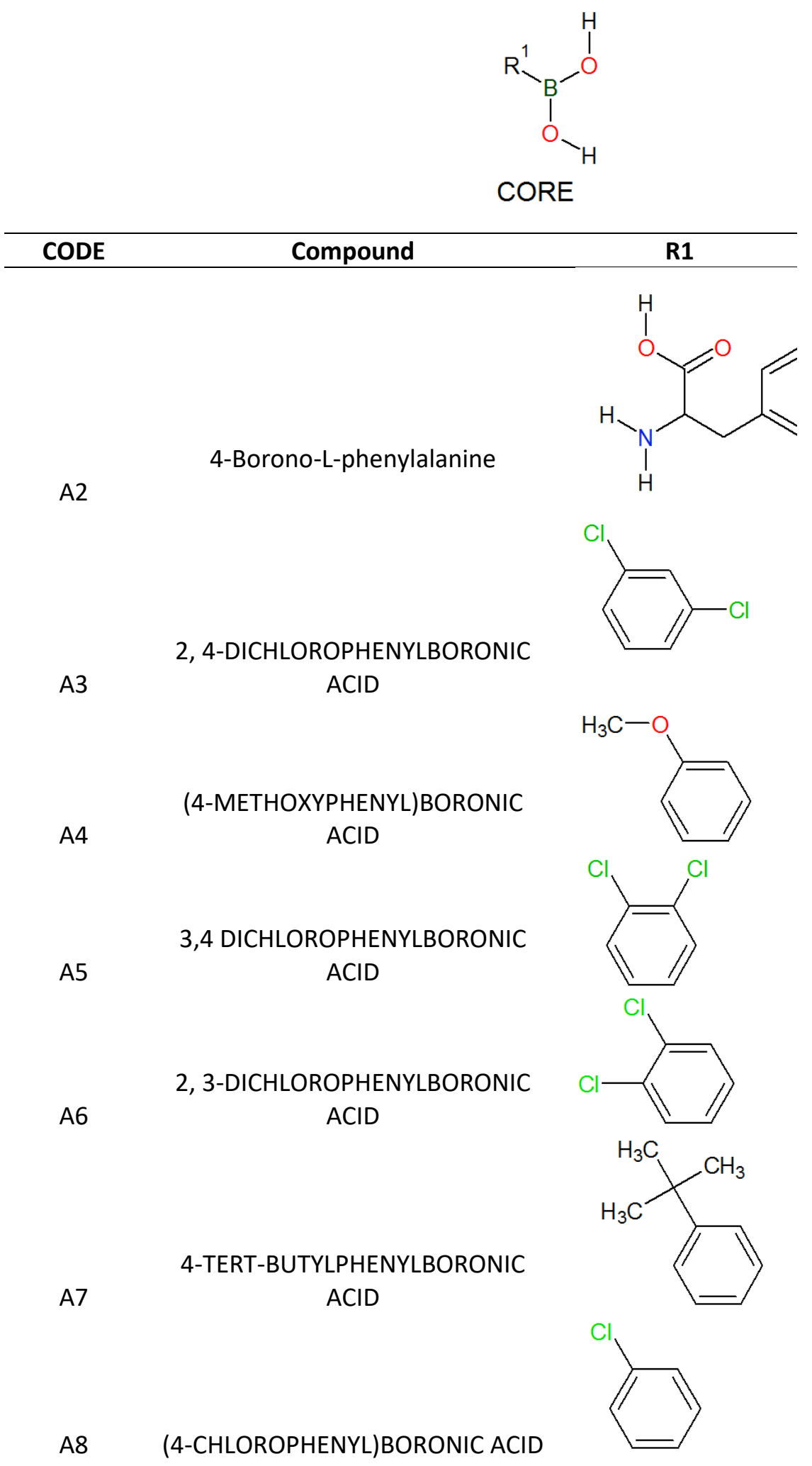


A9 (3-CHLOROPHENYL)BORONIC ACID<smiles>Clc1ccccc1</smiles>

A10 4-FLUOROPHENYLBORONIC ACID<smiles>Fc1ccccc1</smiles>

4-ACETAMIDOPHENYLBORONIC

A11 ACID<smiles>CC(=O)Nc1ccccc1</smiles>

(3-ACETAMIDOPHENYL)BORONIC

A12 ACID

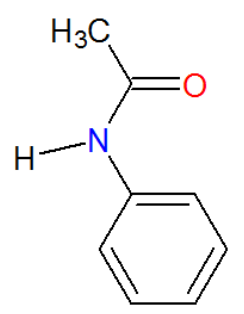

A13

4-(METHYLTHIO)PHENYLBORONIC<smiles>CSc1ccccc1</smiles>

$4-$ (METHYLSULFONYL)PHENYLBORON

A14 IC ACID<smiles>CS(=O)(=O)c1ccccc1</smiles>

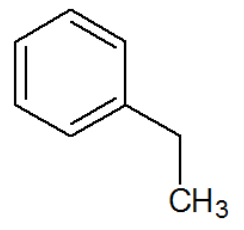

A16 1-PHENYLVINYLBORONIC ACID

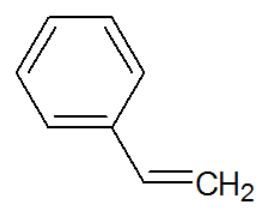<smiles>c1ccccc1</smiles>

PHENYLBORONIC ACID

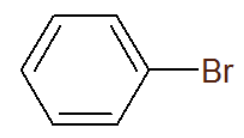


A19 4-BROMOPHENYLBORONIC ACID<smiles>Brc1ccccc1</smiles>

A20 3-AMINOPHENYLBORONIC ACID<smiles>Nc1ccccc1</smiles>

(4AMINOSULFONYLPHENYL)BORONI

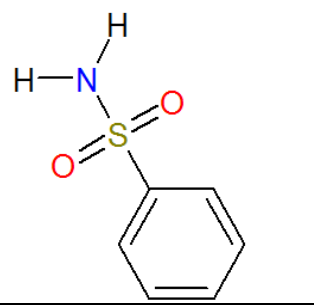


Table 2. Boroxazolidone derivatives included in this study. They are adducts of amino acids and 2aminoethylborinate (A1). Code was assigned and it corresponds to that in the table for affinity values.

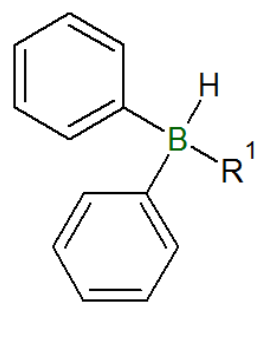

CORE

\begin{tabular}{lll}
\hline CODE & Compound & R1 \\
\hline A1 & 2-AMINOETHYL & DIPHENYLBORINATE
\end{tabular}

BXD-ALA BXD-ALANINE<smiles>[Y]NC(C)C(=O)O[14CH3]</smiles>

BXD-ARG BXD-ARGININE

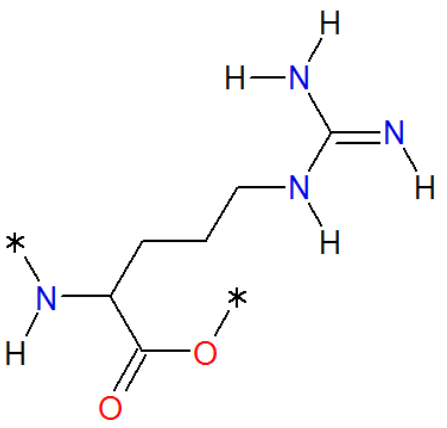

BXD-ASP

BXD-ASPARTIC ACID

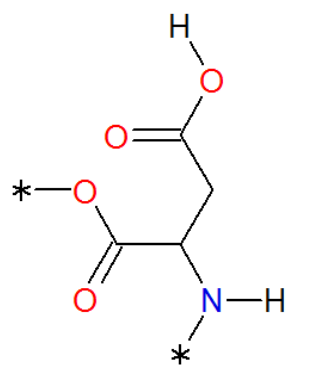


BXD-ASN

BXD-ASPARAGINE

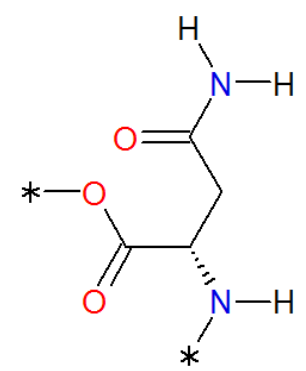

BXD-CYS

BXD-CYSTEINE

BXD-GLN

BXD-GLUTAMINE<smiles>[Z]N[C@H](CS[2H])C(=O)O[Y]</smiles>

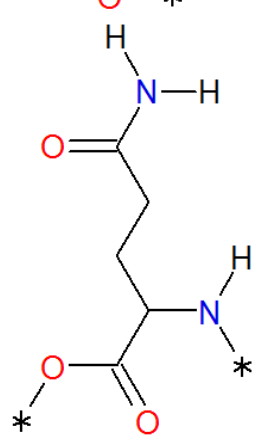

BXD-GLU

BXD-GLUTAMIC ACID

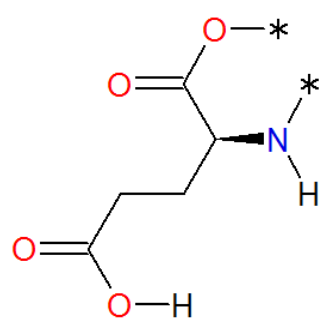

BXD-GLY

BXD-GLYCINE

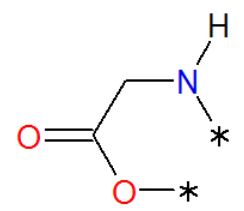

BXD-HIS

BXD-HISTIDINE

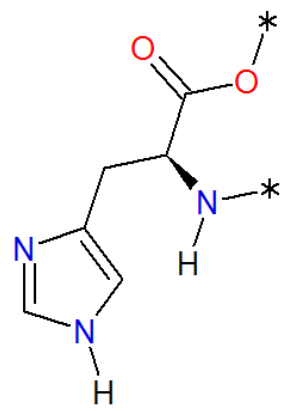




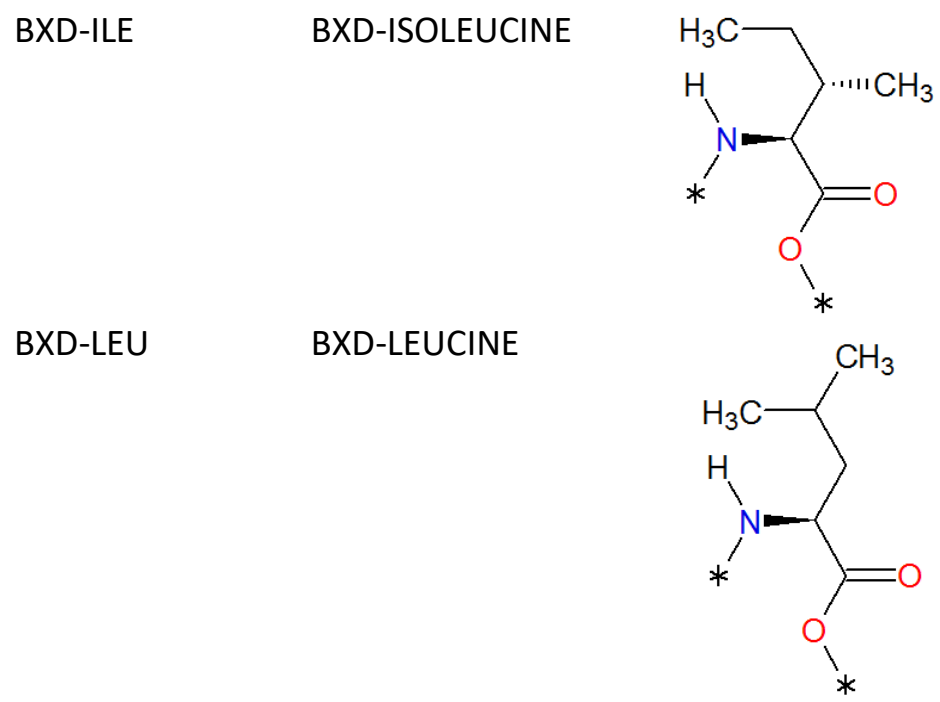

BXD-LYS

BXD-LYSINE

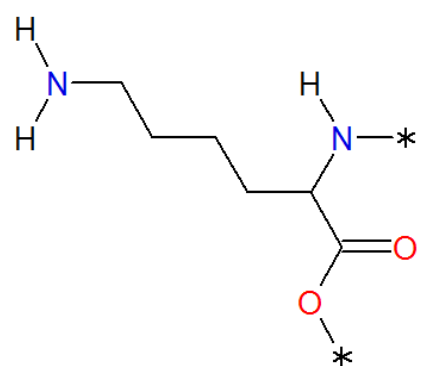

BXD-MET

BXD-METHIONINE

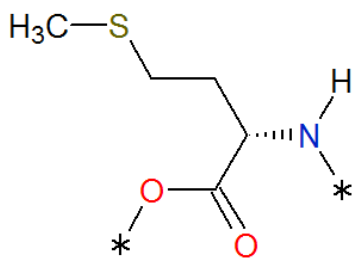

BXD-PRO

BXD-PROLINE

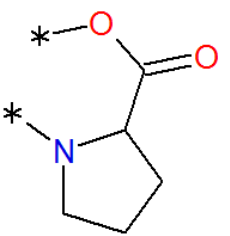

BXD-SER

BXD-SERINE

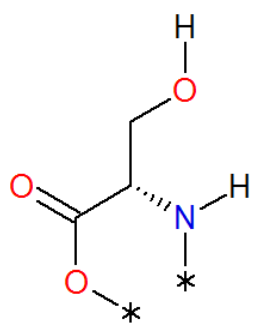


BXD-PHE BXD-

PHENYLALANINE

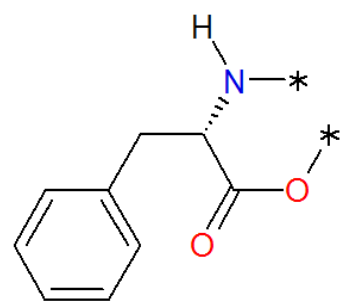

BXD-TRP

BXD-TRYPTOPHAN

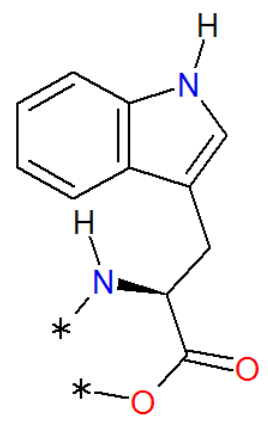

BXD-TYR

BXD-TYROSINE

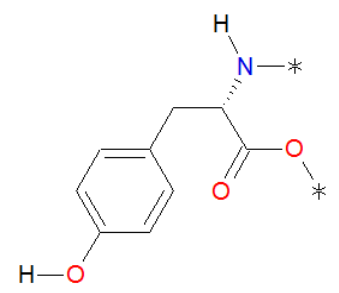

BXD-VAL

BXD-VALINE

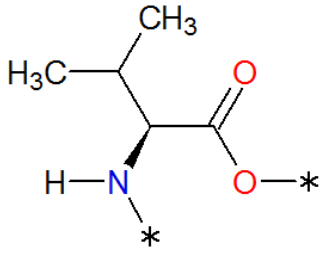

BXD-THR

BXD-THREONINE

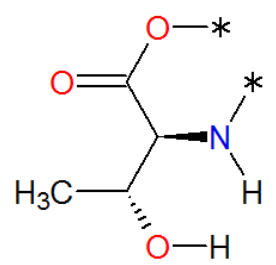


Table 3. Bortezomib and related structure oligopeptides and metabolites. Code was assigned and it corresponds to that in the table for affinity values.

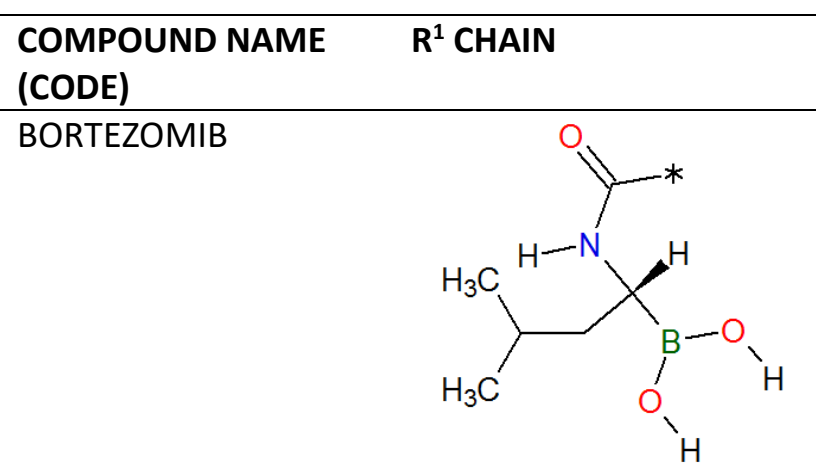

BORTEZOMIB D-

MANNITOL

(Bt-Man)

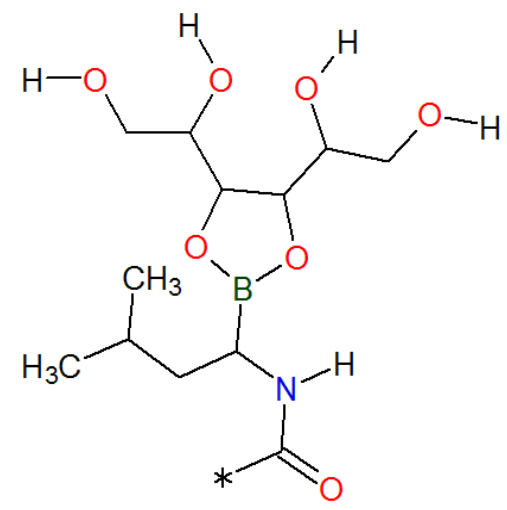

BORTEZOMIB

PINANEDIOL

(Bt-pin)

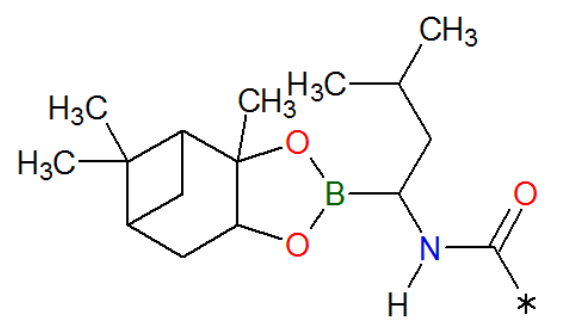

BORTEZOMIB

BORONIC ANHYDRIDE

(Bt-Anh)

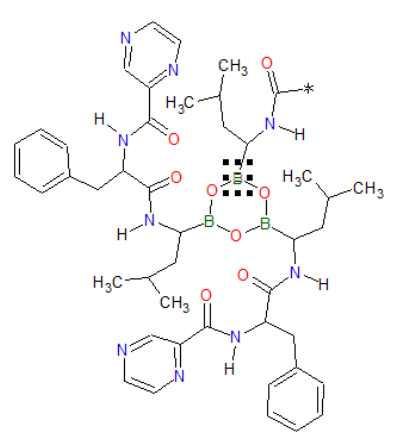

\section{CORE}<smiles>[R]C(Cc1ccccc1)N([TlH])C(=O)c1cnccn1</smiles><smiles>[R]C(Cc1ccccc1)N([TlH])C(=O)c1cnccn1</smiles><smiles>[R]C(Cc1ccccc1)N([TlH])C(=O)c1cnccn1</smiles><smiles>[R]C(Cc1ccccc1)N([TlH])C(=O)c1cnccn1</smiles> 
BORTEZOMIB-D8

(Bt-D8)<smiles>[Z]C(=O)N([2H])C(CC(C)C)B(O)O</smiles><smiles>[R]C(Cc1ccccc1)N([TlH])C(=O)c1cnccn1</smiles>

(1S, 2S), BORTEZOMIB (Bt-1S2S)

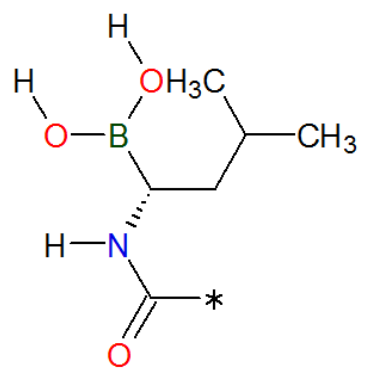<smiles>[R]C(Cc1ccccc1)N([TlH])C(=O)c1cnccn1</smiles>

DESISOBUTYL-NBUTYL BORTEZOMIB (Bt-DN-butil)<smiles>[Z6]C(=O)N[C@H](CCCC)B(O)O</smiles><smiles>[R]C(Cc1ccccc1)N([TlH])C(=O)c1cnccn1</smiles>

(S)-HYDROXY DES(BORIC ACID) BORTEZOMIB (Bt-Hyd)<smiles>[Y6]C(=O)N([2H])[C@H](O)CC(C)C</smiles><smiles>[R]C(Cc1ccccc1)N([TlH])C(=O)c1cnccn1</smiles>

BORTEZOMIB IMPURITY A (Bt-impA)<smiles>[13CH2]C([14CH3])=O</smiles><smiles>[R]C(Cc1ccccc1)N([TlH])C(=O)c1cnccn1</smiles>

BORTEZOMIB IMPURITY B (Bt-impB)<smiles>[13CH3]C(=O)O</smiles><smiles>[R]C(Cc1ccccc1)N([TlH])C(=O)c1cnccn1</smiles> 
IXAZOMIB
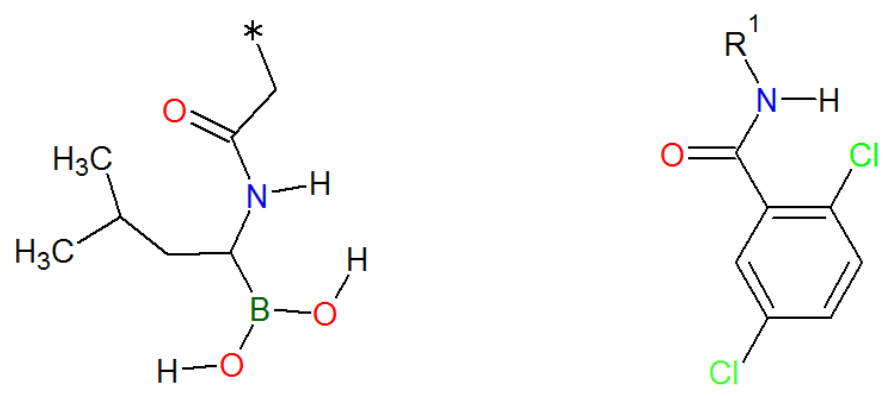

DELANZOMIB
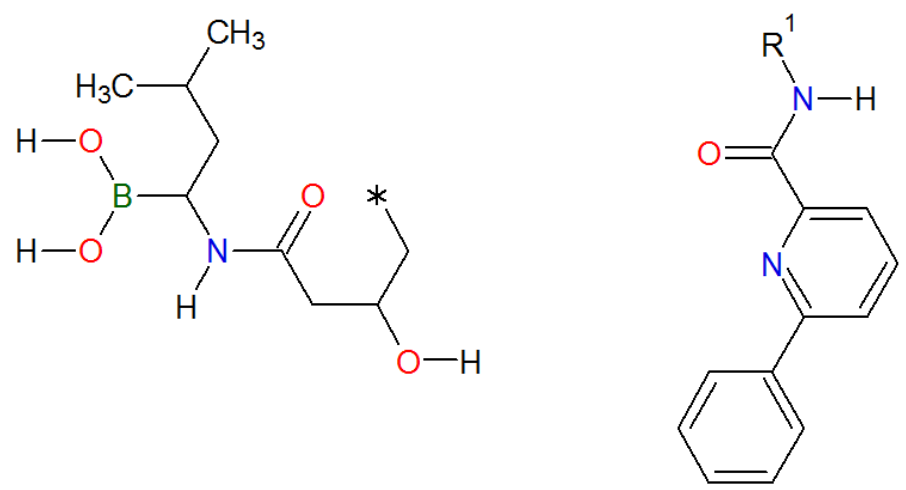
Table 4. BCCs crystallized on viral proteases. Code was assigned as is in the Protein Data Bank (PDB) and it corresponds to that in the table for affinity values.

\begin{tabular}{ll}
\hline NAME & STRUCTURE \\
(CODE) &
\end{tabular}

(1-\{[(10-tert-butyl-15,15-dimethyl-3,9,12trioxo-

$6,7,9,10,11,12,14,15,16,17,18,19,23,23 a-$ tetradecahydro- $1 \mathrm{H}, 5 \mathrm{H}-2,23: 5,8$-dimethano4,13,2,8,11-benzodioxatriazacyclohenicosin7(3H)-yl)carbonyl]amino\}-3hydroxypropyl)(trihydroxy)borate(1-) (TR8)

$\{4-[\{(2 R, 3 S)-3-[(\{[(3 S, 3 a r, 5 R, 7 a s, 8 S)-$ hexahydro-4H-3,5-methanofuro[2,3b]pyran-8-yl]oxy\}carbonyl)amino]-2hydroxy-4-phenylbutyl\}(2methylpropyl)sulfamoyl]phenyl\}boronic acid (Q1D)

$\mathrm{N}$-[(cyclopentyloxy)carbonyl]-3-methyl-Ivalyl-(4r)-n-\{(1r)-3-hydroxy-1[hydroxy(oxido)boranyl]propyl\}-4(isoquinolin-1-yloxy)-I-prolinamide (C8D)

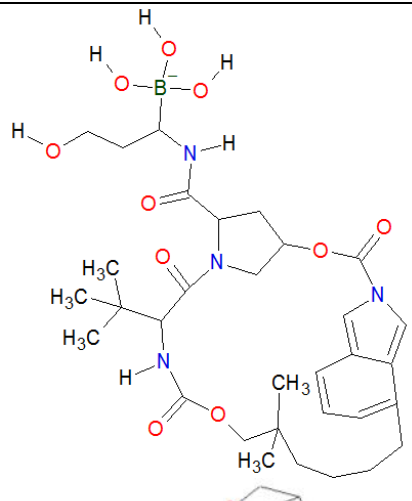

\section{CRYSTALLYZED ON ENZYME (PDB CODE [Reference])}

HCV NS3 protease (2XNI) [2]

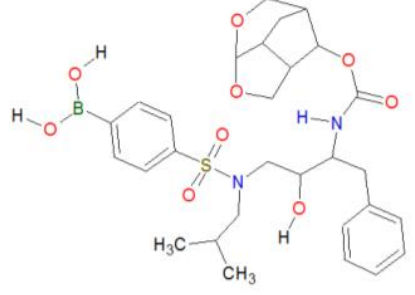

HIV-1 wild type protease

(6U70) [3]<smiles>CC(C)(C)C(B(O)O)C(=O)N1CC(Oc2nccc3ccccc23)CC1C(=O)N(NC(=O)OC1CCCC1)C(CCO)B(O)O</smiles>

HCV NS3 protease $(2 X C N)[4]$

[4- $[[(2 \sim\{R\}, 3 \sim\{S\})-3-$ $[[(3 \sim\{a\} \sim\{S\}, 4 \sim\{R\}, 6 \sim\{a\} \sim\{R\})-$

2,3,3 \{a\},4,5,6 \{a\}-hexahydrofuro[2,3b]furan-4-yl]oxycarbonylamino]-2-oxidanyl4-phenyl-butyl]-(2methylpropyl)sulfamoyl]phenyl]-oxidanyloxidanylidene-boron (BVR)

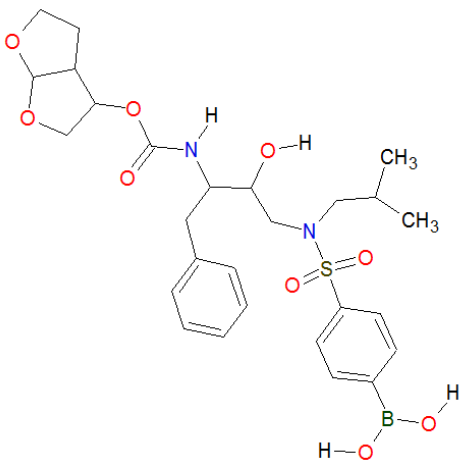

D30N HIV-1 protease

(6C8Y) [5] 
[(1R)-2-cyclobutyl-1-(\{[(1R,2S,5S)-3-(N$\{[(1 \mathrm{~S})$-2,2-dimethyl-1-

$\{[$ methyl(methylsulfonyl)amino]methyl $\}$ pro pyl]carbamoyl $\}$-3-methyl-L-valyl)-6,6dimethyl-3-azabicyclo[3.1.0]hex-2yl]carbonyl \}amino)ethyl]boronic acid (BE8)

((R)-1-((S)-3-(4-(aminomethyl)phenyl)-2benzamidopropaneamido)-4guanidinobutyl)boronic acid (6A8)
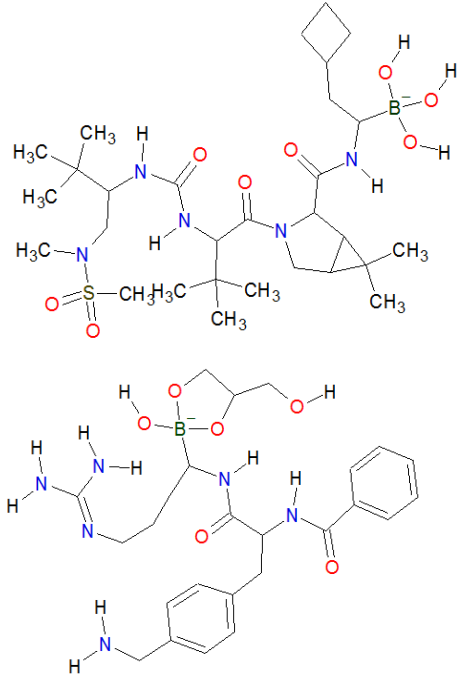

\{4-[\{(2R,3S)-3-[(\{[(3as,4S,7ar)-hexahydro$4 \mathrm{H}$-furo[2,3-b]pyran-4-

yl]oxy\}carbonyl)amino]-2-hydroxy-4phenylbutyl\}(2-

methylpropyl)sulfamoyl]phenyl\}boronic acid (B4R)

$\mathrm{N}-((\mathrm{S})-3-(4-$-aminomethyl)phenyl)-1-(((R)-4guanidino-1-(5-hydroxy-1,3,2-dioxaborinan2-yl)butyl)amino)-1-oxopropan-2yl)benzamide (6T8)
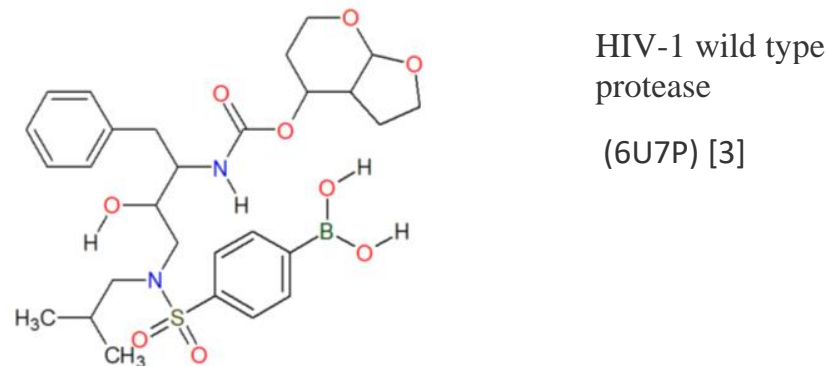

$\mathrm{H}$

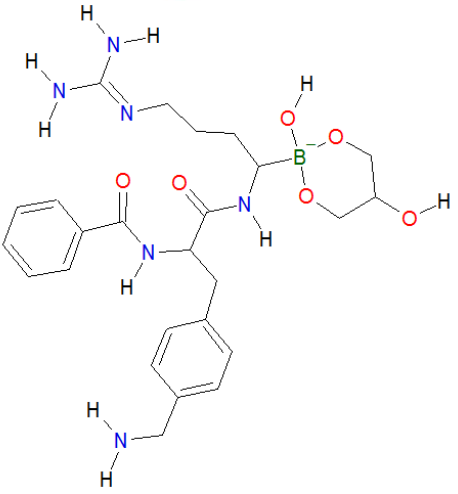

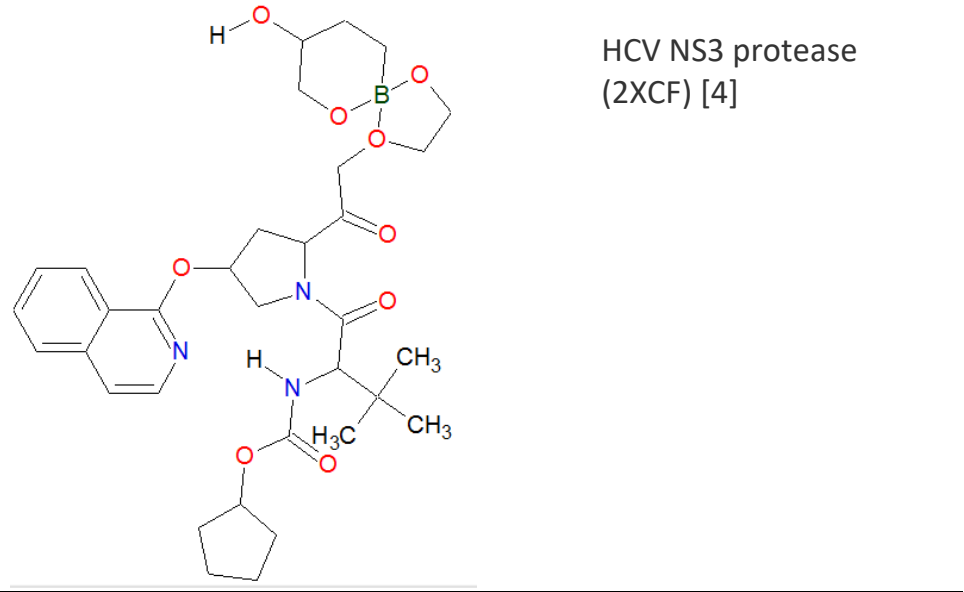

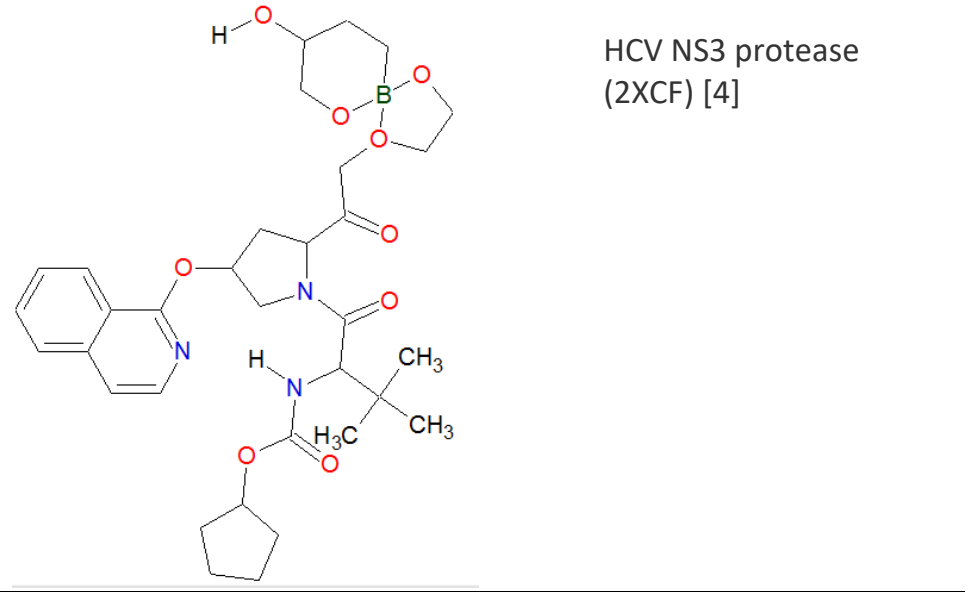

HCV NS3-4A Protease (3EYD) [2]

West Nile Virus NS2BNS3 protease (5IDK)[6] protease

(6U7P) [3]

Zika virus NS2B-NS3 protease

(5LCO) [7]
Cyclopentyl n-[(2s)-1-[(2s,4r)-2-[[(4r)-8hydroxy-1,6,10-trioxa-5\$1^\{4\}boraspiro[4.5]decan-4-yl]carbamoyl]-4isoquinolin-1-yloxy-pyrrolidin-1-yl]-3,3dimethyl-1-oxo-butan-2-yl]carbamate (BBQ) 
Table 5. ZINC derivative compounds, all structurally related to ZINC000541677852, recently identified as a hit compound among 1.3 billion of proposed ligands as Mpro-inhibitors [1]. Code was assigned and it corresponds to that in the table for affinity values.<smiles>[R]N([R])c1cc(C)nn1[R]</smiles>

\section{CORE}

ZINC1

ZINC2
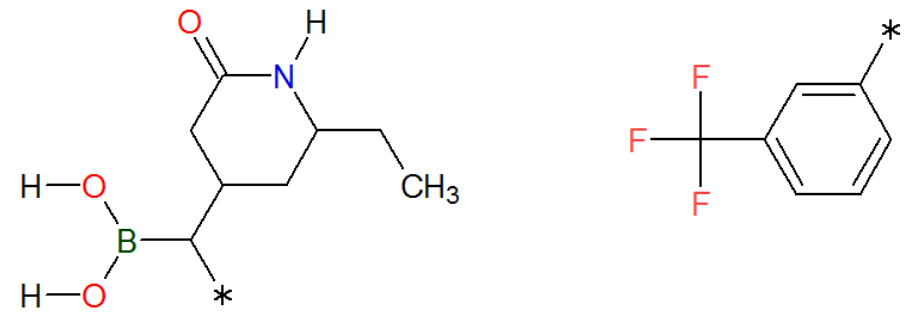

ZINC3<smiles>[Y]C(=O)C1CC(CC)NC(B(O)O)C1</smiles><smiles>[Y]c1cccc(C(F)(F)F)c1</smiles>

ZINC4<smiles>[Y]C(B(O)O)C1CC(CC)N(N)C(B(O)O)C1</smiles><smiles>Cc1cccc(C(F)(F)F)c1</smiles> 
Vega-Valdés et al.

ZINC5

ZINC00541677852
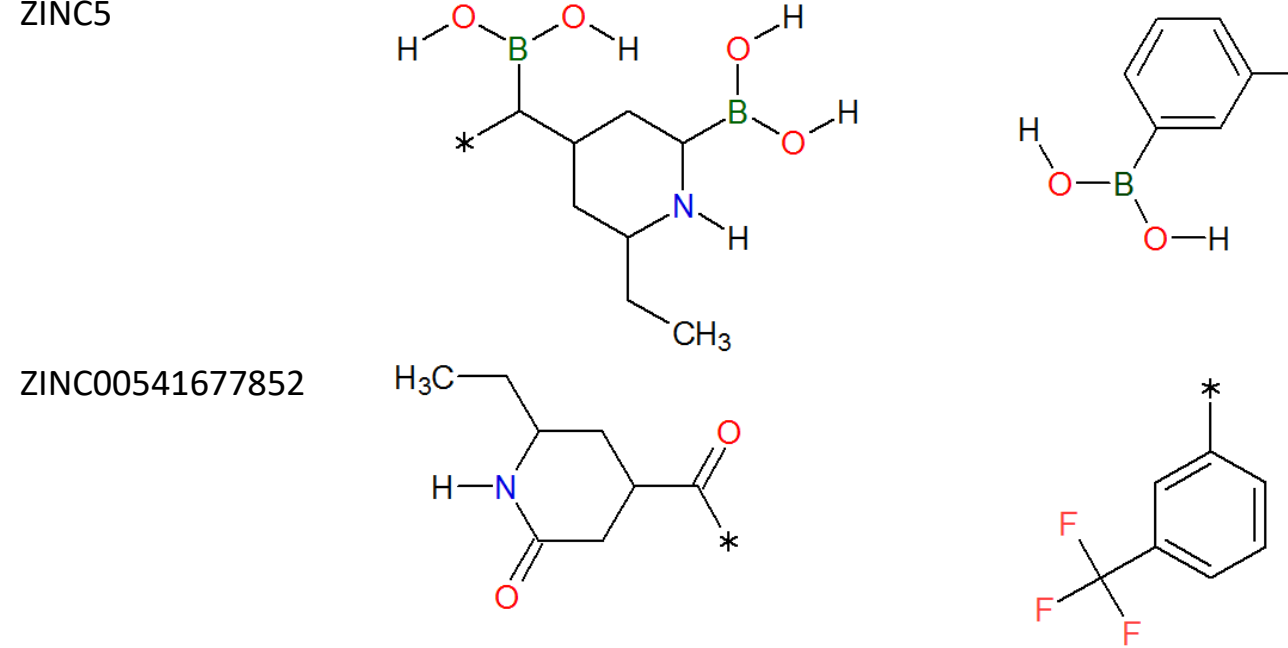
Table 6. Theoretical affinity values on COVID19-Mpro (as is presented in Fig. 3 on the manuscript).

\begin{tabular}{|c|c|c|c|}
\hline & COMPOUND & $\begin{array}{c}\text { Boron-based } \\
\text { (-log Ki) }\end{array}$ & $\begin{array}{c}\text { Carbon-based } \\
\text { (-log Ki) }\end{array}$ \\
\hline 1 & A1 & 5.264830875 & 4.398048596 \\
\hline 2 & $A 2$ & 5.092028682 & 4.471340355 \\
\hline 3 & A3 & 4.570051046 & 3.738308997 \\
\hline 4 & A4 & 4.410090244 & 4.031517051 \\
\hline 5 & A5 & 4.299785662 & 4.691222226 \\
\hline 6 & A6 & 4.288153814 & 3.811634074 \\
\hline 7 & A7 & 5.040050952 & 4.691222226 \\
\hline 8 & A8 & 4.472329531 & 4.104798525 \\
\hline 9 & A9 & 4.496789687 & 4.251424383 \\
\hline 10 & A10 & 3.795543436 & 4.178093623 \\
\hline 11 & A11 & 5.172704165 & 4.398048596 \\
\hline 12 & A12 & 4.889396107 & 4.398048596 \\
\hline 13 & A13 & 4.273414512 & 3.958212681 \\
\hline 14 & A14 & 4.595902985 & 4.324680017 \\
\hline 15 & A15 & 4.837853455 & 4.324680017 \\
\hline 16 & A16 & 4.676566821 & 4.251424383 \\
\hline 17 & A17 & 4.354033949 & 4.104798525 \\
\hline 18 & A18 & 4.273414512 & 3.884922283 \\
\hline 19 & A19 & 4.434668757 & 4.251424383 \\
\hline 20 & $A 20$ & 4.273414512 & 4.031517051 \\
\hline 21 & A21 & 5.158471019 & 4.398048596 \\
\hline 22 & BXD-Ala & 5.079781253 & 4.414200991 \\
\hline 23 & BXD-Arg & 6.047330168 & 5.716698771 \\
\hline 24 & BXD-Asp & 5.240918708 & 5.204119983 \\
\hline 25 & BXD-Asn & 5.402270981 & 4.984221244 \\
\hline 26 & BXD-Cys & 4.91847439 & 4.691222226 \\
\hline 27 & BXD-GIn & 5.563245483 & 5.49757288 \\
\hline
\end{tabular}




\begin{tabular}{|c|c|c|c|}
\hline 28 & BXD-Glu & 5.885731655 & 5.42365865 \\
\hline 29 & BXD-Gly & 5.966024515 & 5.643974143 \\
\hline 30 & BXD-His & 5.724531981 & 5.42365865 \\
\hline 31 & BXD-Ile & 5.402270981 & 5.204119983 \\
\hline 32 & BXD-Leu & 5.321507824 & 4.911155437 \\
\hline 33 & BXD-Lys & 5.160344449 & 4.617982957 \\
\hline 34 & BXD-Met & 5.079781253 & 4.837734386 \\
\hline 35 & BXD-Phe & 6.127272492 & 5.716698771 \\
\hline 36 & BXD-Pro & 5.321507824 & 4.984221244 \\
\hline 37 & BXD-Ser & 5.240918708 & 4.837734386 \\
\hline 38 & BXD-Trp & 5.321507824 & 5.057495894 \\
\hline 39 & BXD-Tyr & 6.770392156 & 5.716698771 \\
\hline 40 & BXD-Thr & 6.047330168 & 5.643974143 \\
\hline 41 & BXD-Val & 5.401104377 & 4.691222226 \\
\hline 42 & Bortezomib & 6.143529317 & 5.42365865 \\
\hline 43 & Delanzomib & 5.966024515 & 4.984221244 \\
\hline 44 & Ixazomib & 5.240918708 & 5.13076828 \\
\hline 45 & Bt-1S2S & 5.982788478 & 5.204119983 \\
\hline 46 & $6 A 8$ & 6.810633714 & 6.15490196 \\
\hline 47 & $6 \mathrm{~T} 8$ & 7.099441366 & 5.790484985 \\
\hline 48 & B4R & 6.832968111 & 5.790484985 \\
\hline 49 & BQQ & 7.131026434 & 5.49757288 \\
\hline 50 & BE8 & 7.053209431 & 5.057495894 \\
\hline 51 & Bt-impA & 6.225511474 & 5.57024772 \\
\hline 52 & Bt-impB & 5.531596566 & 5.204119983 \\
\hline 53 & Bt-Anh & 3.384032693 & 5.204119983 \\
\hline 54 & Bt-D8 & 6.290863296 & 5.204119983 \\
\hline 55 & Bt-D-man & 5.839810359 & 5.204119983 \\
\hline 56 & Bt-pin & 7.595236977 & 6.008773924 \\
\hline 57 & BVR & 6.837580363 & 5.57024772 \\
\hline
\end{tabular}




\begin{tabular}{lcrr}
58 & C8D & 6.887027655 & 5.13076828 \\
59 & Bt-DN-butil & 6.200026822 & 4.691222226 \\
60 & Q1D & 7.421888355 & 5.643974143 \\
61 & Bt-Hyd & 6.129051727 & 5.204119983 \\
62 & TR8 & 7.143171989 & 5.790484985 \\
63 & ZINC1 & 7.117739561 & 6.086186148 \\
64 & ZINC2 & 6.456632855 & 5.935542011 \\
65 & ZINC3 & 6.193862557 & 6.229147988 \\
66 & ZINC4 & 6.642718815 & 5.790484985 \\
67 & ZINC5 & 6.156567427 & 5.13076828 \\
68 & ZINC00541677852 & 6.590539811 & 6.008773924 \\
\hline
\end{tabular}




\section{References:}

[1] Ton, A.-T.; Gentile, F.; Hsing, M.; Ban, F.; Cherkasov, A. Rapid Identification of Potential Inhibitors of SARS- CoV-2 Main Protease by Deep Docking of 1.3 Billion Compounds. Mol. Inform., 2020. doi.org/10.1002/minf.202000028

[2] Li, X.; Zhang, Y.K.; Liu, Y.; Ding, C.Z.; Zhou, Y.; Li, Q.; Plattner, J.J.; Baker, S.J.; Zhang, S.; Kazmierski, W.M.; Wright, L.L.; Smith, G.K.; Grimes, R.M.; Crosby, R.M.; Creech, K.L.; Carballo, L.H.; Slater, M.J.; Jarvest, R.L.; Thommes, P.; Hubbard, J.A.; Convery, M.A.; Nassau, P.M.; McDowell, W.; Skarzynski, T.J.; Qian, X.; Fan, D.; Liao, L.; Ni, Z.J.; Pennicott, L.E.; Zou, W.; Wright, J. Novel Macrocyclic HCV NS3 Protease Inhibitors Derived from $\alpha$-Amino Cyclic Boronates. Bioorganic Med. Chem. Lett., 2010, 20 (19), 5695-5700.

[3] Ghosh, A.K.; Xia, Z.; Kovela, S.; Robinson, W.L.; Johnson, M.E.; Kneller, D.W.; Wang, Y.F.; Aoki, M.; Takamatsu, Y.; Weber, I.T.; Mitsuya, H. Potent HIV-1 Protease Inhibitors Containing Carboxylic and Boronic Acids: Effect on Enzyme Inhibition and Antiviral Activity and Protein-Ligand X-Ray Structural Studies. ChemMedChem, 2019, 14 (21), 1863-1872.

[4] Li, X.; Zhang, Y.K.; Liu, Y.; Ding, C.Z.; Li, Q.; Zhou, Y.; Plattner, J.J.; Baker, S.J.; Qian, X.; Fan, D.; Liao, L.; Ni, Z.J.; White, G. V.; Mordaunt, J.E.; Lazarides, L.X.; Slater, M.J.; Jarvest, R.L.; Thommes, P.; Ellis, M.; Edge, C.M.; Hubbard, J.A.; Somers, D.; Rowland, P.; Nassau, P.; McDowell, B.; Skarzynski, T.J.; Kazmierski, W.M.; Grimes, R.M.; Wright, L.L.; Smith, G.K.; Zou, W.; Wright, J.; Pennicott, L.E. Synthesis and Evaluation of Novel $\alpha$-Amino Cyclic Boronates as Inhibitors of HCV NS3 Protease. Bioorganic Med. Chem. Lett., 2010, 20 (12), 3550-3556.

[5] Windsor, I.W.; Palte, M.J.; Lukesh, J.C.; Gold, B.; Forest, K.T.; Raines, R.T. Sub-Picomolar Inhibition of HIV-1 Protease with a Boronic Acid. J. Am. Chem. Soc., 2018, 140, 43, 1401514018.

[6] Nitsche, C.; Zhang, L.; Weigel, L.F.; Schilz, J.; Graf, D.; Bartenschlager, R.; Hilgenfeld, R.; Klein, C.D. Peptide-Boronic Acid Inhibitors of Flaviviral Proteases: Medicinal Chemistry and Structural Biology. J. Med. Chem., 2017, 60, 1, 511-516.

[7] Lei, J.; Hansen, G.; Nitsche, C.; Klein, C.D.; Zhang, L.; Hilgenfeld, R. Crystal Structure of Zika Virus Ns2b-Ns3 Protease in Complex with a Boronate Inhibitor. Science, 2016, 353 (6298), 503-505. 